\section{Changes of thermocline depth at the Sumba Island offshore based on planktonic foraminiferal assemblages and its implication to eutrophication since the Last Deglaciation ( $18 \mathrm{ka} \mathrm{BP})$ : a preliminary study}

Rudarsko-geološko-naftni zbornik

(The Mining-Geology-Petroleum Engineering Bulletin) UDC: $56 ; 550.8 ; 551.58 ; 551.8$

DOI: $10.17794 / \operatorname{rgn} .2021 .3 .3$

Original scientific paper

\author{
Ryan Dwi Wahyu Ardi ${ }^{1,2}$; Aswan'; Khoiril Anwar Maryunani'; Eko Yulianto ${ }^{1}$; Purna Sulastya Putra ${ }^{1,3}$; \\ Septriono Hari Nugroho ${ }^{1,3}$ \\ ${ }^{1}$ Geological Engineering Study Program, Faculty of Earth Science and Technology, Institut Teknologi Bandung, \\ Jl. Ganesha No. 10 Bandung 40132 \\ ${ }^{2}$ Agrotechnology Study Program, Faculty of Science and Technology, Universitas Nahdlatul Ulama Purwokerto, \\ Jl. Sultan Agung No. 42 Purwokerto 53144 \\ ${ }^{3}$ Research Center for Geotechnology, Indonesian Institute of Sciences, Jl. Sangkuriang Kompleks LIPI Bandung 40135 \\ https://orcid.org/0000-0002-4417-5852 (PSP)
}

\begin{abstract}
Changes of the thermocline depth (DOT) at the Sumba Island offshore are not well-known compared to the DOT changes in the Timor Sea, the main exit passage of the Indonesian Through-flow (ITF). Planktonic foraminiferal assemblages in cores collected from the southwest Sumba offshore (STo8) and Sumba Strait (ST12, ST13, and ST14) were used as a tool to infer the DOT and paleoproductivity changes at the Sumba Island offshore. The DOT changes were indicated from the thermocline and mixed layer dwellers' relative abundance while the paleoproductivity changes were indicated from the relative abundance of Neogloboquadrina dutertrei. This study suggests a contrast between the DOT pattern at the Sumba Island offshore and the DOT pattern in the Timor Sea during the Last Deglaciation-Holocene. The contrast DOT pattern indicated that the multi-millennial changes of the Australian-Indonesian monsoon (AIM) during the Last DeglaciationHolocene were the main factors behind the DOT changes in this region while the effects of El Niño Southern Oscillation (ENSO) -like, Indian Ocean Dipole (IOD) -like, and ITF to DOT changes were minimal. Paleoproductivity enhancement at the Sumba Island offshore was not solely related to the monsoon-driven coastal upwelling intensification, which resulted in the DOT shoaling and eutrophic condition. The increase of nutrient availability in surface water due to river runoff increase and changes in the lifted water mass nature were also able to enhance productivity in this region.
\end{abstract}

Keywords:

Australian-Indonesian monsoon; applied micropaleontology; Indonesian Throughflow; Lesser Sunda Islands; paleoceanography

\section{Introduction}

The Depth of Thermocline (DOT), which is the distance between the upper limit of the thermocline layer and the ocean surface (Lana et al., 2017), is one of the most studied parameters in paleoceanographic studies (Spooner et al., 2005; Ding et al., 2013; Kwiatkowski et al., 2015). The study of the DOT changes is important due to their association with the variation of upwelling intensity and marine productivity (Brasier, 1995; Müller and Opdyke, 2000; Holbourn et al., 2005). The increase of the upwelling intensity is indicated in the shoaling of the DOT which triggers the eutrophication process as the nutrient-rich cool water layer reaches the photic zone (Brasier, 1995; Susanto et al., 2001). This condition is also known as eutrophic, which is associated with the regime of higher marine productivity (Brasier, 1995; Spooner et al., 2005; Andruleit et al., 2008).

Corresponding author: Ryan Dwi Wahyu Ardi

dwa.ryan@students.itb.ac.id; dwa.ryan@gmail.com
On the other hand, the condition when the nutrient-rich cool water layer does not reach the photic zone is known as oligotrophic, associated with the regime of lower marine productivity (Brasier, 1995; Spooner et al., 2005; Andruleit et al., 2008).

The DOT in the Indonesian region varies spatially with the shallower DOT in its western part and the deeper DOT in its eastern part (Lana et al., 2017). The shallower DOT in western Indonesia is associated with the development of coastal upwelling at the south Sumatra offshore-Lesser Sunda Islands, also known as the Java upwelling region, especially during the Australia-Indonesian winter monsoon (AIWM) (Susanto et al., 2001, 2006; Andruleit et al., 2008). In eastern Indonesia, the upwelling-related DOT shoaling is hindered by the maximum flow of ITF's surface water, and as a result, the DOT is relatively deeper than in western Indonesia (Gordon and Fine, 1996; Lana et al., 2017). On the glacial-interglacial scale, changes in the DOT are also related to the changes of the Australia-Indonesian monsoon (AIM) configuration and the hydrographic changes 


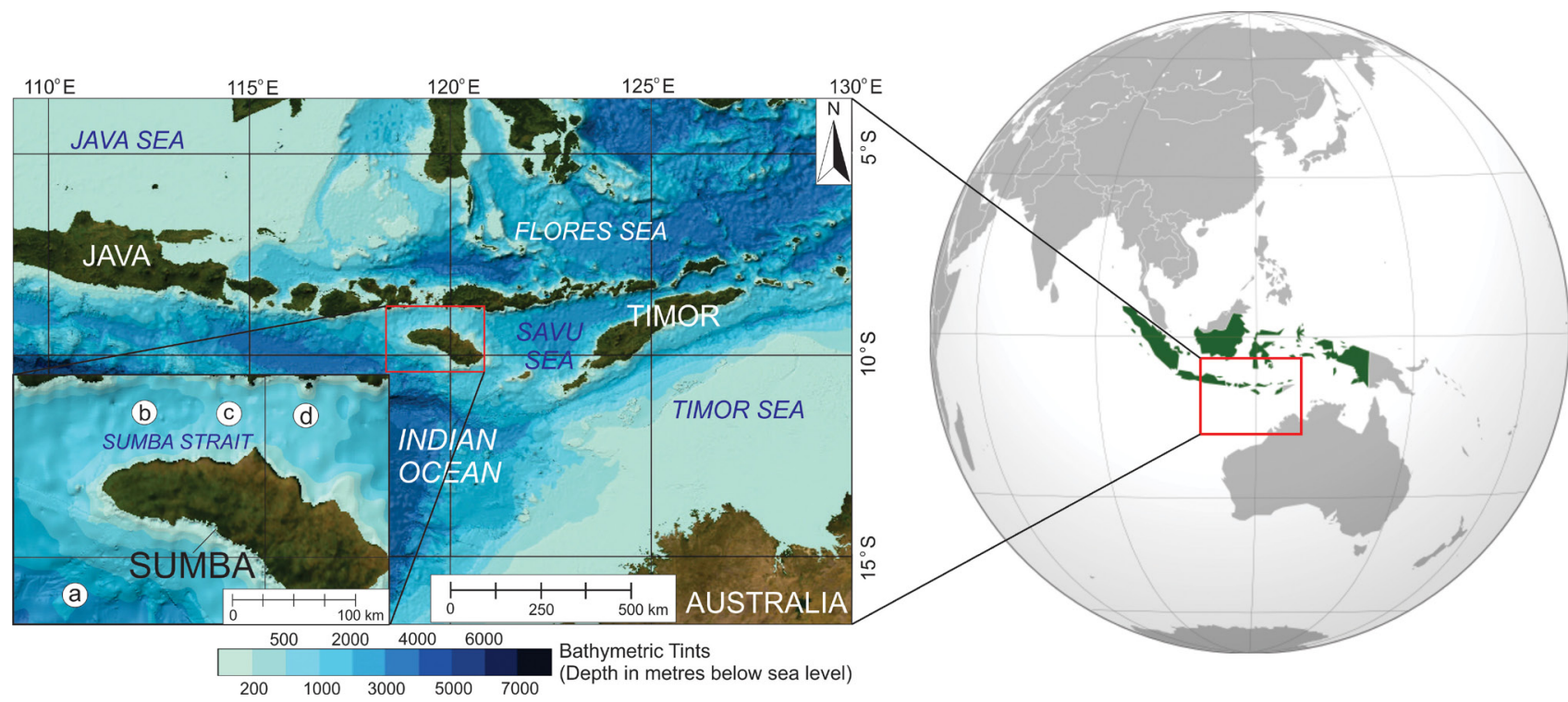

Figure 1: Locations of gravity cores collection on the southwest Sumba offshore and Sumba Strait: STo8 (a), ST14 (b), ST13 (c), and ST12 (d). Bathymetric data were obtained from GEBCO Bathymetric Compilation Group 2020 (2020).

of ITF (Kuhnt et al., 2004; Spooner et al., 2005; Holbourn et al., 2011; Ding et al., 2013). During the Last Glacial-Deglaciation, the DOT became shallower due to the perpetual occurrence of AIWM in southern Indonesia, except in the main ITF outflow region (the Timor Sea), while the paleoproductivity in this region was generally higher (Kuhnt et al., 2004; Holbourn et al., 2005, 2011; Xu et al., 2006; Ding et al., 2013). In the Java upwelling region, the increased paleoproductivity was caused by the enhanced coastal upwelling (Andruleit et al., 2008; Lückge et al., 2009; Mohtadi et al., 2011a). The enhanced paleoproductivity in the Timor Sea was associated with the exposure of Sahul Shelf which enhanced the nutrient supply to the ocean (Kuhnt et al., 2004; Kawamura et al., 2006; Capelli et al., 2016) and the hydrographic change of ITF's water mass related to the slowdown of thermohaline circulation during the Last Glacial-Deglaciation (Martínez et al., 1999; Xu et al., 2006). During the Holocene, the paleoproductivity was generally lower and the DOT shoaling was only indicated in the Timor Sea (Kuhnt et al., 2004; Holbourn et al., 2005, 2011; Xu et al., 2006). The lower paleoproductivity was related to the weakened coastal upwelling and the submerged Sahul Shelf (Holbourn et al., 2005; Kawamura et al., 2006; Capelli et al., 2016).

The Sumba Island offshore is situated at the confluence of the ITF's exit passage and the Java upwelling region. The mechanism for the past DOT and paleoproductivity changes is still not well understood in this region, as most of the previous studies focused on the main ITF exit passage (Timor Sea) (Müller and Opdyke, 2000; Kuhnt et al., 2004; Holbourn et al., 2005, 2011; Xu et al., 2006, 2008; Xu, 2014), and similar studies on minor paths (i.e. Ombai Strait and Sumba Strait) are still scarce (Steinke et al., 2014b; Ardi et al., 2019; Putra and Nugroho, 2020).
This preliminary research aimed to reveal the mechanism of paleoproductivity changes at the Sumba Island offshore, were they accompanied by the DOT changes? In this research, the DOT and paleoproductivity changes were inferred from foraminiferal assemblages of three marine sediment (gravity) cores taken from Sumba Strait (ST12, ST13, and ST14) and a gravity core taken from southwest Sumba offshore (ST08) (see Figure 1).

\section{Climate and Oceanographic Setting}

The oceanography of the Indonesian seas is highly influenced by the AIM and ITF (Gordon, 2005; Ding et al., 2013; Sprintall and Révelard, 2014). The semiannual latitudinal shifts of the Inter-tropical Convergence Zone (ITCZ) result in the contrast climate condition between Australian-Indonesian summer monsoon (AISM) (December-March) and AIWM (April-September) (Mohtadi et al., 2016; Wang et al., 2017). The peak of AISM coincides with the southern hemisphere/ austral summer when the ITCZ lies around the latitude of Northern Australia, while the AIWM reaches its peak during the northern hemisphere/boreal summer when the ITCZ lies around the latitude of Indochina (Wheeler and McBride, 2005; Yim et al., 2014; Huang et al., 2015) (see Figure 2). During the AISM, the northwest winds bring the moisture-rich air to the Indonesia region and induce the wet season, while the drier southeast winds during AIWM deliver the dry season (Wheeler and McBride, 2005). The rainfall difference between the wet and dry seasons in the Indonesian region is most prominent in its southern part (from Southern Sumatra to the Lesser Sunda Islands) which indicates the stronger monsoon influence (Aldrian and Susanto, 2003; Mohtadi et al., 2007). 


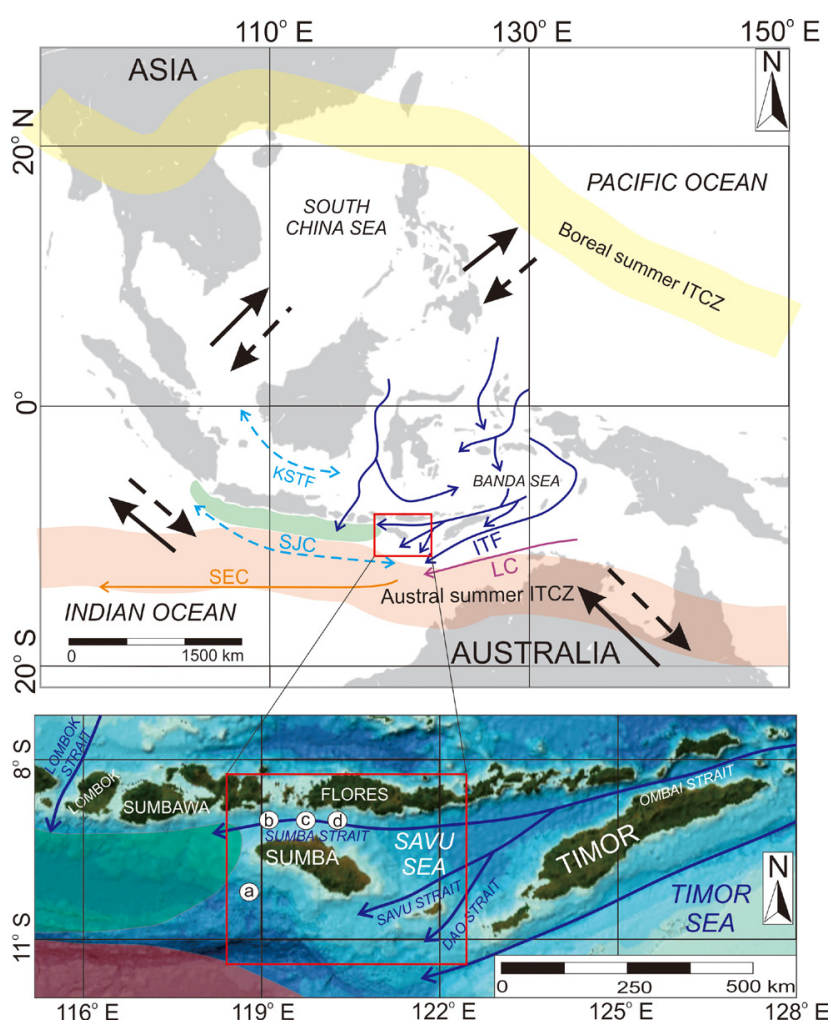

Figure 2: Modern climate and oceanography of Indonesia adapted from several authors (Gordon, 2oo5; Qu et al., 2005; Andruleit et al., 2008; Sprintall et al., 2009; Ningsih et al., 2013; Kuhnt et al., 2015; Wang et al., 2017; Bayhaqi et al., 2019). Red-outlined rectangular indicates the study area, white circles indicate the location of the studied cores (a. STo8, b. ST14, c. ST13, and d. ST12), blue arrows indicate ITF routes, cyan dashed arrows indicate the seasonally reversed currents (SJC and KSTF), the purple arrow indicates LC, orange arrow indicates SEC, green shading indicates the Java upwelling region, yellow shading indicates the Boreal summer ITCZ and red shading indicates the Austral summer ITCZ. Bathymetric data were obtained from GEBCO Bathymetric Compilation Group 2020 (2020).

During AISM, the northwest winds bring the warm and relatively fresh surface waters from the South China Sea, Karimata Strait, and the Java Sea to the southern tip of Makassar Strait and the Flores Sea in the form of Karimata Strait Through-flow (KSTF) (Tomczak and Godfrey, 2003; Qu et al., 2005) (see Figure 2). This water mass blocks the ITF surface water and causes the formation of thermocline-dominated ITF, which in turn causes shoaling of the DOT in the ITF exit passage (Gordon et al., 2003; Qu et al., 2005). The northwest winds also affect the direction of another surface current, i.e. South Java Current (SJC), which flows to the southeast, bringing the water mass from the equatorial Indian Ocean to the Timor Sea before merging with the Leeuwin Current (LC), and the water mass from ITF to form the South Equatorial Current (SEC) (Schott and McCreary, 2001; Tomczak and Godfrey, 2003; Spooner et al., 2005) (see Figure 2). During AIWM, the southeast winds cause the KSTF and SJC to flow in the opposite direction (to the northwest) (Schott and McCreary, 2001; Tomczak and Godfrey, 2003; Qu et al., 2005). The northwest flow of KSTF dismisses the surface water barrier in the southern tip of Makassar Strait, thus allows the ITF surface water to enter the Flores Sea, causing the DOT shoaling in the ITF exit passage (Gordon et al., 2003; Qu et al., 2005). The occurrence of ITF's surface and thermocline water indicates that the intensity of ITF is relatively higher and reaches its maximum around August (Tomczak and Godfrey, 2003). The northwest flow of KSTF draws surface water masses from the Flores and Banda Sea, which triggers the minor upwelling in the Banda Sea (Spooner et al., 2005; Brijker et al., 2007). During this time, the SJC flows northwest and brings the water mass from the ITF exit passage to the equatorial Indian Ocean (Schott and McCreary, 2001; Tomczak and Godfrey, 2003). The northwest flow of SJC triggers the seasonal coastal upwelling in the Java upwelling region, which reaches its maximum around August (Susanto et al., 2001; Ningsih et al., 2013).

Most of the ITF water mass ( $\sim 15 \mathrm{~Sv})$ enters the Indian Ocean through its main exit passage, which is the Timor Sea ( 7.5 Sv), while some of it passes through the Lombok Strait $(\sim 2.6 \mathrm{~Sv})$ and Ombai Strait $(\sim 4.9 \mathrm{~Sv})$ (Sprintall et al., 2009). The ITF water mass that flows through the Ombai Strait enters the Savu Sea before diverging to the Sumba Strait and the Savu/Dao Straits (Potemra et al., 2003; Sprintall et al., 2009). A recent study by Bayhaqi et al. (2019) revealed very small transport of ITF $(\sim 0.1 \mathrm{~Sv})$ that flows through the Sumba Strait compared to the Savu/Dao Straits.

On an interannual scale, the oceanography of the Indonesian region is influenced by the El Niño Southern Oscillation (ENSO) and Indian Ocean Dipole (IOD), especially the upwelling intensity (Ningsih et al., 2013; Chen et al., 2016; Kusuma et al., 2017; Hendrawan et al., 2019). The occurrence of El Niño (La Niña) and positive (negative) IOD phases is associated with the more (less) intense coastal upwelling due to the anomalous stronger southeast (northwest) winds (Susanto et al., 2001; Sprintall et al., 2003; Ningsih et al., 2013). ENSO-like and IOD-like mechanisms, which are defined as the occurrence of several periods with more frequent El Niño/La Niña/positive IOD/negative IOD phase at millennial - multi-millennial scale, are also inferred in the Indonesia region (Brijker et al., 2007; Abram et al., 2009; Kwiatkowski et al., 2015; Feng et al., 2018).

\section{Material and Methods}

Four gravity cores collected during the 2016 Widya Nusantara Expedition (E-WIN) from off southwest Sumba (ST08) and from Sumba Strait (ST12, ST13, and ST14) were used as the research materials (see Table 1). The samples for foraminifera determination and count- 
Table 1: Gravity cores used in this study

\begin{tabular}{|l|l|l|l|l|l|}
\hline \multirow{2}{*}{ Core } & \multirow{2}{*}{ Location } & Coordinate & $\begin{array}{l}\text { Depth } \\
\text { (metres below sea level) }\end{array}$ & Length (cm) \\
\cline { 3 - 6 } & & Longitude $\left({ }^{\circ} \mathbf{E}\right)$ & Latitude $\left({ }^{\circ}\right.$ S) & 2966 & 236 \\
\hline ST08 & Off southwest Sumba & 118.772 & 10.195 & 830 & 223 \\
\hline ST12 & Sumba Strait & 120.243 & 9.068 & 1004 & 173 \\
\hline ST13 & Sumba Strait & 119.740 & 9.072 & 1283 & 243 \\
\hline ST14 & Sumba Strait & 119.245 & 9.079 & & \\
\hline
\end{tabular}

Table 2: AMS ${ }^{14} \mathrm{C}$ ages and calibrated ${ }^{14} \mathrm{C}$ ages of core STo8 (Ardi, 2018)

\begin{tabular}{|l|l|l|l|l|}
\hline Lab Code & Depth Intervals & Materials & ${ }^{14}$ C age (BP) & Calibrated ${ }^{14}$ C age BP \\
\hline Beta-492272 & $24-25 \mathrm{~cm}$ & Foraminifera : Neogloboquadrina spp. & $3330 \pm 30$ & $3236-2938$ \\
\hline Beta-492271 & $74-75 \mathrm{~cm}$ & Foraminifera : Neogloboquadrina spp. & $4880 \pm 30$ & $5272-4948$ \\
\hline Beta-492270 & $104-105 \mathrm{~cm}$ & Foraminifera : Neogloboquadrina spp. & $6390 \pm 30$ & $6920-6660$ \\
\hline Beta-449813 & $166-167 \mathrm{~cm}$ & Bulk Sediment & $11930 \pm 30$ & $13430-13330(13375)$ \\
\hline Beta-449814 & $235-236 \mathrm{~cm}$ & Bulk Sediment & $15510 \pm 50$ & $18480-18255(18360)$ \\
\hline
\end{tabular}

ing were taken following the sampling procedure of Ardi (2018), Ardi et al. (2019), Damanik et al. (2019), and Putra and Nugroho (2020). A total of 250 sub-samples were collected and $\sim 5 \mathrm{~g}$ from each sub-sample were prepared using the swirling method (without $\mathrm{H}_{2} \mathrm{O}_{2}$ ) to disengage the foraminifera specimens from the mud. Each sample was washed on the top of 200 mesh $(0.074$ $\mathrm{mm}$ ) sieve and the residue was dried at the temperature of $60^{\circ} \mathrm{C}$ for $\sim 6$ hours.

Quantitative determination of foraminiferal taxa was preceded by splitting the prepared sample until $\sim 300$ specimens of foraminifera were present in each part. All identified taxa in one part were counted while new taxa detected in the remaining parts were counted as one specimen even after normalization. The foraminiferal counts were normalized against the number of splits and the weight of the samples (Ardi et al., 2019). Planktonic foraminifera descriptions by Kenneth and Srinivasan (1983) and Bolli and Saunders (1985) were referred. The sample preparations and the determination and counting of foraminifera were conducted at the Sedimentary Laboratory of the Research Center for Geotechnology of the Indonesian Institute of Science (LIPI) and the Micropaleontology Laboratory of Institut Teknologi Bandung (ITB).

Accelerator Mass Spectrometer-measured radiocarbon (AMS ${ }^{14} \mathrm{C}$ ) ages were only available on five depth intervals of core ST08 (see Table 2) (Ardi, 2018). The radiocarbon ages were converted to calibrated calendar and radiocarbon ages with High Probability Density Range (HPD) Method (Bronk Ramsey, 2009) (for 24$25 \mathrm{~cm}, 74-75 \mathrm{~cm}$, and 104-105 cm depth intervals), and the intercept of radiocarbon age with calibration curve (Talma and Vogel, 1993) (for 166-167 cm and 235-236 $\mathrm{cm}$ depth intervals) based on the MARINE13 calibration datasets (Reimer et al., 2013). The age model for the core ST08 was generated using the Clam package (version 2.3.4) on R (Blaauw, 2010, 2020; R Core Team,
2013). This standard statistic approach is the better choice to rapidly and systematically produce age-models for the low-resolution dating sites since the use of complicated Bayesian age-modeling methods might not add much accuracy and precision (Blaauw, 2010). Twenty runs were done, and a model with the lowest goodness-of-fit (-log) was chosen. This model employed linear interpolation, weighted average-based calendar age point estimates for depths, and the standard Gaussian distribution. The core top sediment was assumed to be aged -66 Before Present (BP) (Present=1950 Anno Domini/AD, core ST08 was retrieved in 2016) and the sedimentation rates between the aged intervals were assumed to be constant (see Figure 3 and Table 3). The sedimentation rates abruptly increased in 25-74 and 75-104 cm depth intervals which were coeval to Mid Holocene, while the sedimentation rates of $0-24 \mathrm{~cm}$, $105-166 \mathrm{~cm}$, and $167-236 \mathrm{~cm}$ depth intervals (coeval to Late Holocene, Late Deglaciation-Early Holocene, and Early Deglaciation) were relatively lower (see Figure 3). Relative age based on planktonic foraminiferal zonation (Bolli and Saunders, 1985) was also utilized to establish the chronological framework in this study. Pleistocene-aged sediments were only inferred on core ST08, ST13, and ST14 while Holocene-aged sediments were inferred on all cores, including core ST12.

The relative abundances of thermocline dwellers (i.e. Pulleniatina obliqueloculata, Neogloboquadrina spp. and Globorotalia spp.) and mixed layer dwellers (i.e. Globigerinoides ruber, Globigerinoides trilobus, and other Globigerinoides taxa) planktonic foraminifera (ratio of the total number of thermocline/mixed layer dwellers against the total number of planktonic foraminifera in a subsample) (see Supplementary Materials) were used to infer the changes in the DOT, as suggested by Bé et al. (1977) and Ravelo et al. (1990). The shoaling (deepening) of the DOT was indicated by the increase 

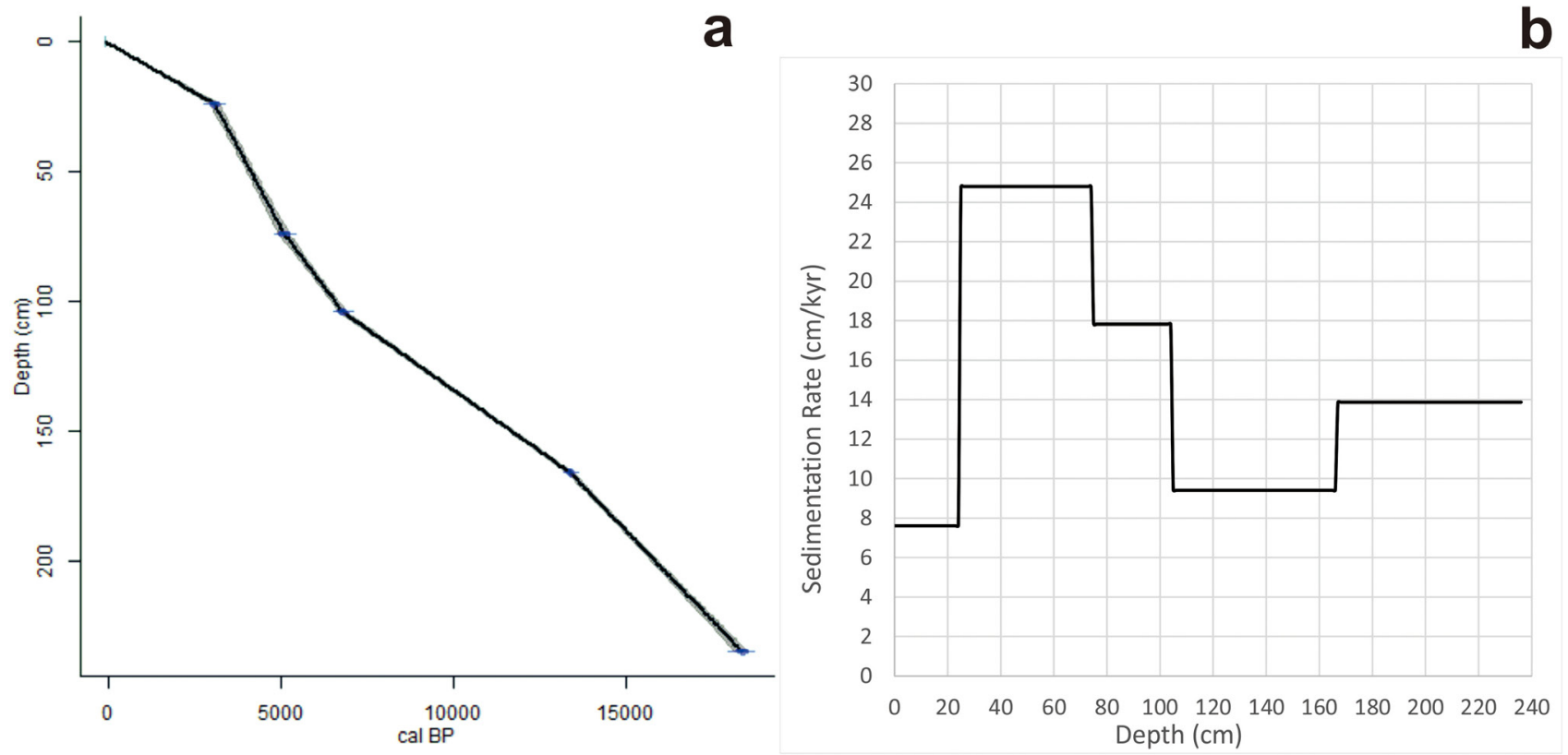

Figure 3: Age model based on the standard statistic approach using the Clam package on $\mathrm{R}$ (Blaauw, 2010, 2020; R Core Team, 2013). The best-estimated ages are hinted by the bold line (a). Sedimentation rates between the aged depth intervals (b).

Table 3: Sedimentation rates used in the age model, obtained from the Clam package on $\mathrm{R}$

(Blaauw, 2010, 2020; R Core Team, 2013).

\begin{tabular}{|l|l|}
\hline Depth intervals & Sedimentation rates (cm/ka) \\
\hline $0-25 \mathrm{~cm}$ & 7.602 \\
\hline $25-75 \mathrm{~cm}$ & 24.802 \\
\hline $75-105 \mathrm{~cm}$ & 17.825 \\
\hline $105-167 \mathrm{~cm}$ & 9.407 \\
\hline $167-236 \mathrm{~cm}$ & 13.864 \\
\hline
\end{tabular}

(decrease) of the thermocline (mix layer) dwellers' abundance (Ravelo et al., 1990; Spooner et al., 2005; Maryunani, 2009; Ding et al., 2013; Steinke et al., 2014b). The relative abundance of Neogloboquadrina (N.) dutertrei (ratio of the $N$. dutertrei against the total number of planktonic foraminifera in a subsample) (see Supplementary Materials), a typical taxon that prefers to live in a high productivity condition around the Deep Chlorophyll Maximum (DCM) layer, was used to infer the paleoproductivity (Barmawidjaja et al., 1993; Spooner et al., 2005; Mohtadi et al., 2007; Zhang et al., 2016, 2019).

\section{Results and Discussion}

The proxies used in this study (thermocline dwellers, mixed layer dwellers, and $N$. dutertrei) exhibit changes within the Holocene and Pleistocene (Last Deglaciation) periods. Spatial differences of thermocline dwellers, mix layer dwellers, and $N$. dutertrei changes are also observed in the research area.

\subsection{Core STo8 (off southwest Sumba)}

Based on the age model of core ST08 (see Figure 3), the first occurrence (FO) of Globorotalia (Gl.) fimbriata which indicates the beginning of the Holocene is coeval to $\sim 11$ ka BP (see Figure 4). The abrupt changes in thermocline dwellers, shallow dwellers, and $N$. dutertrei were observed around this time, which indicated a contrast abundance pattern during the Last Deglaciation, and the Holocene. Thermocline dwellers and $N$. dutertrei were significantly higher during the Last Deglaciation and significantly lower during the Holocene, however, less notable changes were also observed within the Last Deglaciation and Holocene intervals (see Figures 5 and 6). Less notable increases of thermocline dwellers were indicated around Mid Holocene $(80-120 \mathrm{~cm}$ and 60-65 cm intervals) and Late Holocene (0-20 cm interval) (see Figure 5). $N$. dutertre $i$ was slightly increased around Mid Holocene (80-120 cm interval) and slightly decreased around Mid Deglaciation (180-200 cm interval) (see Figure 6). Mixed layer dwellers showed a contradictive pattern compared to the thermocline dwellers and $N$. dutertrei with lower abundance during the Last Deglaciation and higher abundance during the Holocene (see Figure 7). During the Holocene, minor decreases are detected around Mid Holocene (90-115 cm and 60$65 \mathrm{~cm}$ intervals) and Late Holocene (0-20 cm interval).

The higher abundance of thermocline dwellers and the lower abundance of mixed layer dwellers indicated a shallower DOT during the Last Deglaciation compared to the Holocene (see Figures 5 and 7). Minor increases of the thermocline dwellers and minor decreases of the mixed layer dwellers around the Mid and Late Holocene 
also indicated DOT shoaling but to a lesser extent. Paleoproductivity was higher during the Last Deglaciation and lower during the Holocene (see Figure 6). A minor decrease of paleoproductivity was indicated around the Mid Deglaciation while its minor increase occurred around the Mid Holocene (see Figure 6).

\subsection{Core ST14 (western Sumba Strait)}

The pattern of the thermocline and mixed layer dwellers were similar to the core ST08 but with a less obvious shift (see Figures 5 and 7). The shift of the thermocline and mixed layer dwellers occurred earlier compared to the core ST08, which was around the Late Deglaciation ( 170-180 cm interval) (see Figures 5 and 7). A minor increase of thermocline dwellers and a minor decrease of mixed layer dwellers were also observed around the Late Holocene (0-30 cm interval). The abundance of $N$. dutertrei was more constant with a more obvious increase observed around the Mid Deglaciation (150-170 $\mathrm{cm}$ interval) and a less significant increase around the Mid Holocene (40-60 cm interval) (see Figure 6).

A shallower DOT was indicated during the Last Deglaciation, but a deepening of the DOT occurred earlier compared to the southwest Sumba offshore (around the Late Deglaciation). In addition, the shoaling of the DOT around the Mid Holocene was not detected (see Figures 5 and 7). Minor DOT shoaling was also indicated around the Late Holocene, as the abundance of thermocline dwellers was gradually increased, and the abundance of mixed layer dwellers decreased gradually. Paleoproductivity was mostly constant with a more significant increase around the Mid Deglaciation and a less significant increase around the Mid Holocene (see Figure 6).

\subsection{Core ST13 (central Sumba Strait)}

The pattern of the thermocline dwellers and $N$. dutertrei was relatively constant around the Last Deglaciation-Early Holocene (90 cm-bottom interval) and gradually increased afterward (0-90 cm interval) (see Figure 5 and 6). Mixed layer dwellers were less abundant during the Last Deglaciation until the earliest interval of Holocene (140 cm-bottom interval), before increasing around the Early Holocene (80-140 cm interval), and decreased gradually since the Mid Holocene (see Figure 7).

The DOT was relatively constant during the Late Deglaciation-Early Holocene before it gradually shoaled since the Mid Holocene (see Figures 5 and 7). Paleoproductivity also indicated a similar pattern which gradually increased since the Mid Holocene (see Figure 6).

\subsection{Core ST12 (eastern Sumba Strait)}

Core ST12 only recorded Holocene-aged sediments, indicated by the occurrence of Gl. fimbriata even in its lowest interval. The abundance of thermocline dwellers was slightly lower around the Early Holocene $(100 \mathrm{~cm}-$ bottom interval) compared to around Late Holocene (0-80 cm interval) while a significant decrease was observed around the Mid Holocene (80-110 cm interval) and a minor decrease was observed around the Late Holocene (0-20 cm interval) (see Figure 5). The abundance pattern of mixed layer dwellers mirrors the thermocline dwellers with a significant increase around Mid Holocene (80-110 cm interval) and a minor increase around the Late Holocene (0-20 cm interval) (see Figure 7). A significant decrease of $N$. dutertrei was indicated around the Mid Holocene (70-140 cm interval) while the higher abundance of $N$. dutertre $i$ was observed around the Early Holocene (140 cm-bottom interval) and around the Late Holocene $(0-70 \mathrm{~cm}$ interval) (see Figure 6).

During the Holocene, the shoaling of DOT occurred twice on the eastern Sumba Strait. The more significant DOT shoaling occurred around Mid Holocene, while the less significant DOT shoaling occurred around Late Holocene (see Figures 5 and 7). A paleoproductivity decrease was indicated around the Mid Holocene, while around the Late Holocene, it was increased (see Figure 6).

\subsection{The mechanism of DOT and paleoproductivity changes}

Based on the analyzed proxies, the DOT at the Sumba Island offshore (southwest Sumba offshore and Sumba Strait) got shallower during the Last Deglaciation and deeper during the Holocene, as it was opposed to the DOT at the Timor Sea, the main exit passage of ITF (Xu et al., 2008; Holbourn et al., 2011; Kuhnt et al., 2015). This indicated that the glacial-interglacial hydrographic changes of ITF were not the main driver for the past DOT changes, but the multi-millennial changes of the AIM. DOT and paleoproductivity changes within the Holocene and Last Deglaciation periods are also inferred.

DOT shoaling at the Last Deglaciation was caused by the enhancement of coastal upwelling due to the stronger AIWM during this period (Spooner et al., 2005; Mohtadi et al., 2011a; Ding et al., 2013). Stronger AIWM during the Last Deglaciation was associated with the northward shift of the Austral summer ITCZ to around the latitude of Flores Island (Figure 8) hence the AISM northwest winds couldn't reach the Sumba Island offshore (Spooner et al., 2005; Xu et al., 2006; Ding et al., 2013; Kuhnt et al., 2015; Ishiwa et al., 2019). The enhanced coastal upwelling during this period resulted in the eutrophic condition indicated by higher paleoproductivity in the southern Indonesia region (Ding et al., 2013; Xu, 2014), including the Sumba Island offshore. A slight decrease of paleoproductivity around Mid Deglaciation (see Figure 6) was most likely not related to the upwelling intensity, as the DOT remained constant. The change of the lifted water mass characteristics was suggested as the cause for the paleoproductivity reduction. The lifted water mass was most likely the North 
ST08

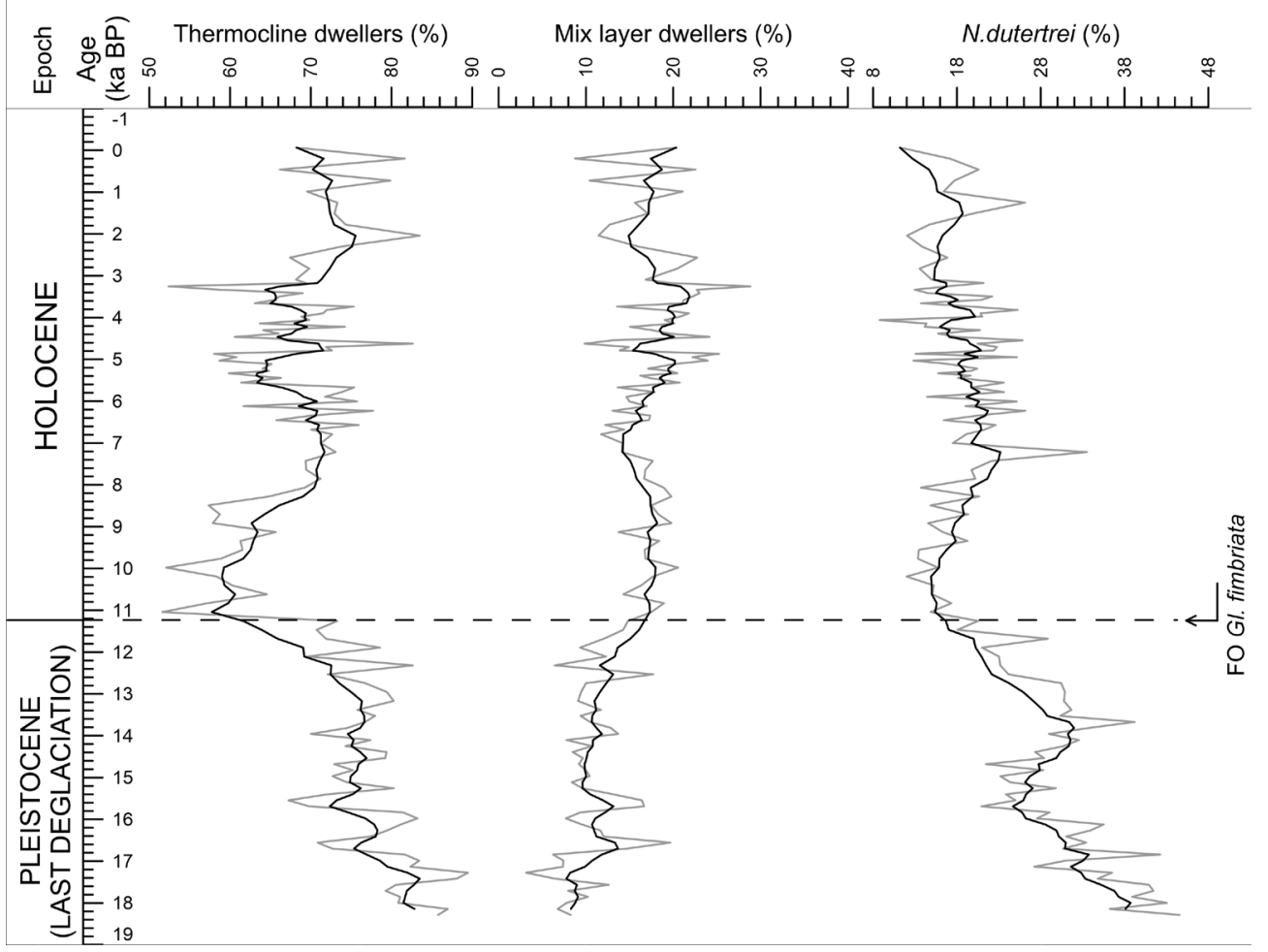

Figure 4: Plot of thermocline dwellers, mixed layer dwellers, and N. dutertrei abundances (\%) of core STo8 based on the age model. The dashed line indicates the FO of Gl. fimbriata (Pleistocene-Holocene boundary).

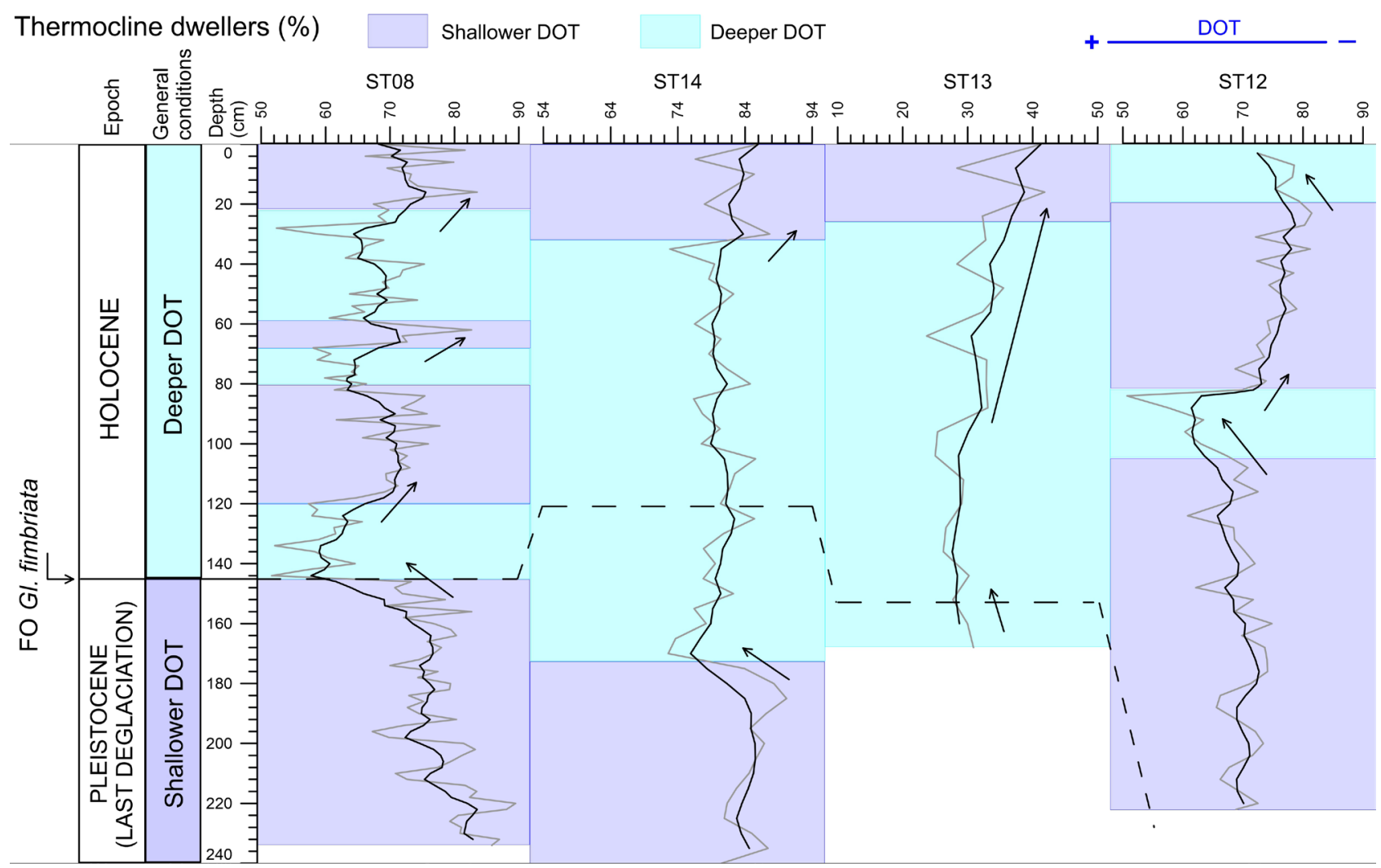

Figure 5: Thermocline dwellers abundances (\%) of core STo8, ST14, ST13, and ST12 against depth. The dashed line indicates the FO of Gl. fimbriata (Pleistocene-Holocene boundary). 


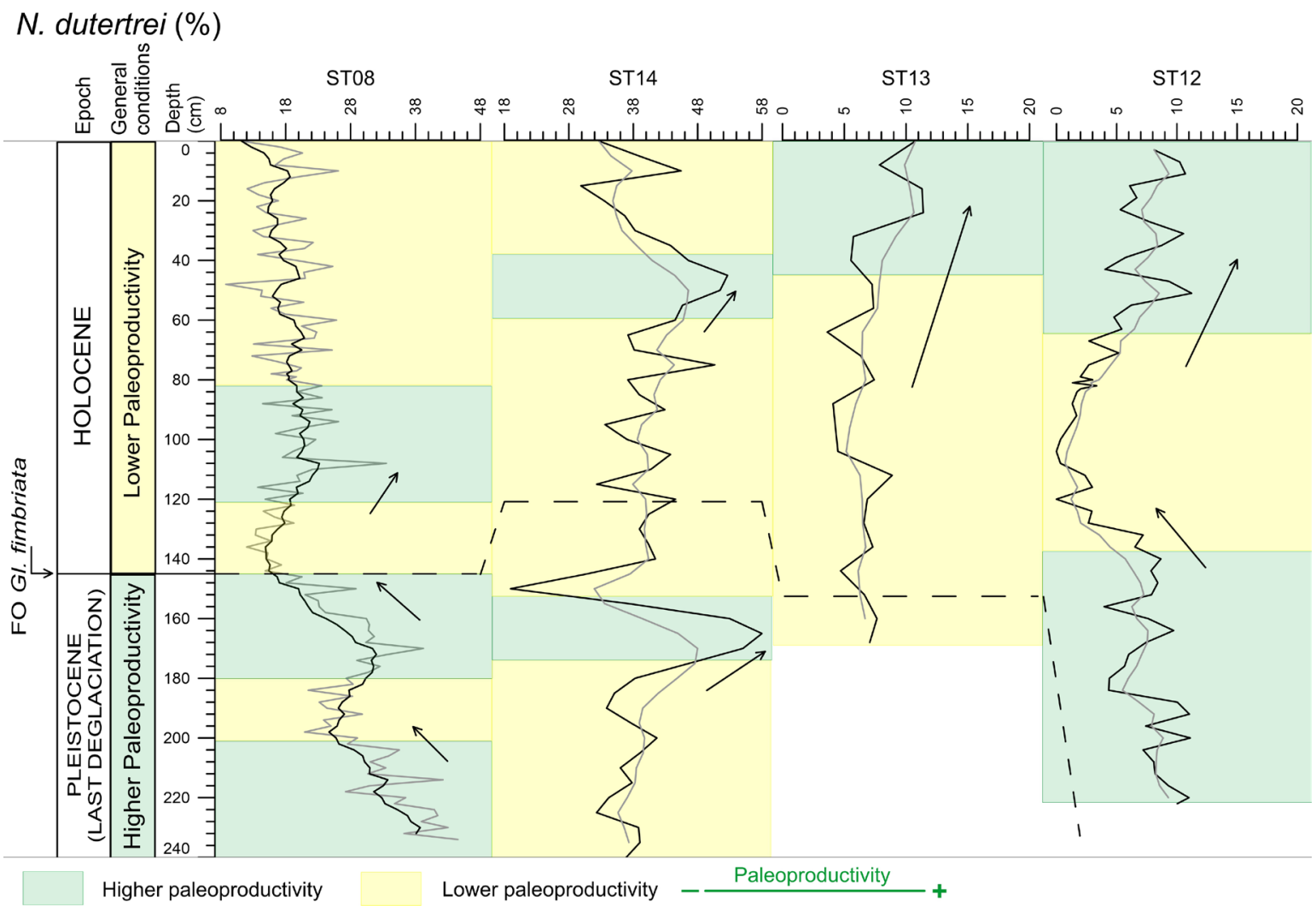

Figure 6: $N$. dutertrei abundances (\%) of core STo8, ST14, ST13, and ST12. The dashed line indicates the FO of Gl. fimbriata (Pleistocene-Holocene boundary).

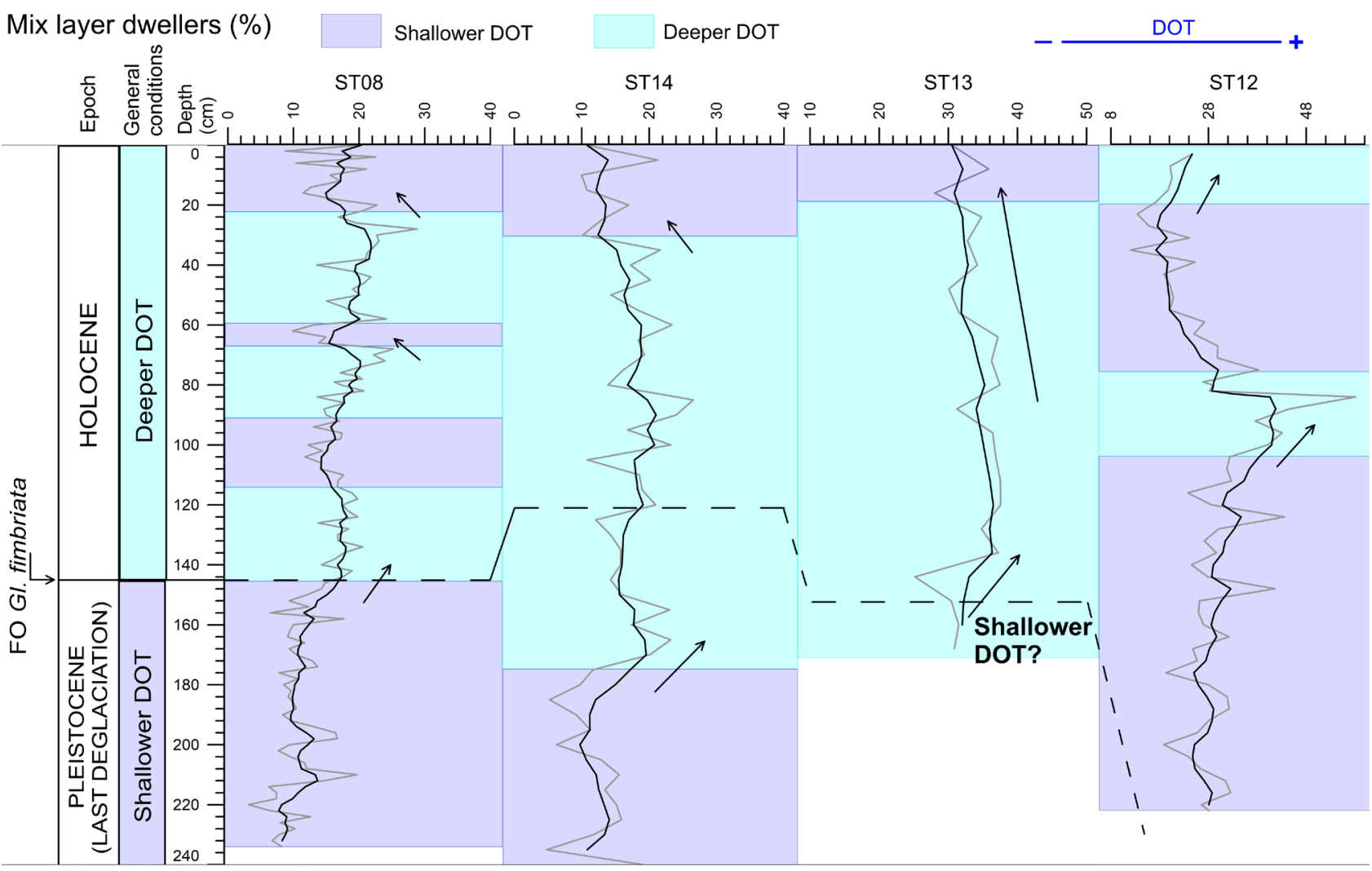

Figure 7: Mixed layer dwellers abundances (\%)of core STo8, ST14, ST13, and ST12 against depth. The dashed line indicates the FO of Gl. fimbriata (Pleistocene-Holocene boundary). 


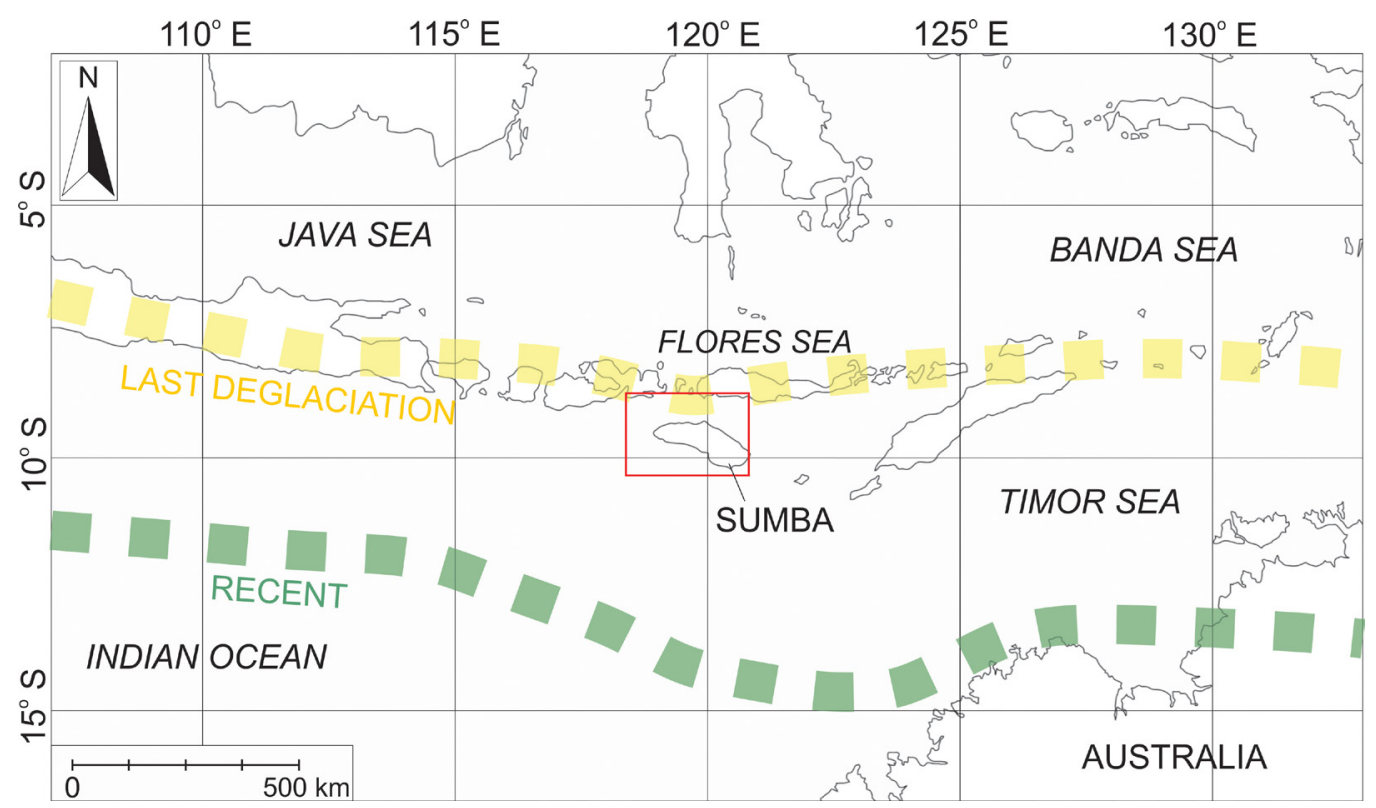

Figure 8: The southern limit of Austral summer ITCZ: present-day condition (the green dashed line) and tentative position during the Last Deglaciation (yellow dashed lines) (Kuhnt et al., 2015; Ardi et al., 2020).

The red-lined rectangular indicates the study area.

Pacific Intermediate Water (NPIW) which entered the sea off Sumba Island as a part of the ITF (Bayhaqi et al., 2019). The changes in the characteristics of ITF water mass were related to the strengthening (weakening) of Atlantic Meridional Ocean Circulation (AMOC) during the Last Deglaciation warm (cold) periods which accelerated (stalled) the thermohaline circulation (Kuhnt et al., 2004; Xu et al., 2006; Levi et al., 2007; Deplazes et al., 2013; Gibbons et al., 2014; Lynch-Stieglitz et al., 2014). The freshening and the warming of the thermohaline circulation water mass due to the melting of the North Atlantic ice sheets during the Last Deglaciation warm periods most likely resulted in a more nutrientdepleted water mass, and thus, a reduction in the paleoproductivity (Deplazes et al., 2013; Lynch-Stieglitz et al., 2014; Hendrizan et al., 2017).

The earlier DOT deepening and paleoproductivity reduction (around the Late Deglaciation) in the Sumba Strait (cores ST12, ST13, and ST14) might be related to its northward position compared to the southwest Sumba offshore (core ST08), thus the AISM reactivated earlier as the Austral summer ITCZ gradually shifted southward (Wyrwoll and Miller, 2001; Kuhnt et al., 2015). Despite the lower abundance of mixed-layer dwellers on the central Sumba Strait around the Late Deglaciation, DOT shoaling did not occur due to the relatively lower abundance of thermocline dwellers. Thermocline dwellers consist of the dissolution-resistant taxa (Ravelo et al., 1990; Martínez et al., 1999), thus their relative abundance changes are more robust as a proxy for the DOT. In southwest Sumba offshore, which is located southward, the AISM reactivation most likely occurred around the Last Deglaciation-Holocene transition. The lower interval of ST14 (170 cm-bottom interval) (west- ern Sumba Strait), which indicated lower paleoproductivity, is most likely coeval to the $180-200 \mathrm{~cm}$ interval of ST08 (southwest Sumba offshore). This indicated that the Early Deglaciation sediment records were only available in the southwest Sumba offshore (ST08) core.

Around the Mid Holocene, DOT shoaling accompanied by higher paleoproductivity (eutrophic condition) only occurred at southwest Sumba offshore. The shoaling of DOT and eutrophic condition was most likely caused by the stronger AIWM (Steinke et al., 2014b; Ardi et al., 2020) which enhanced the coastal upwelling, similar to the DOT shoaling mechanism during the Last Deglaciation (Spooner et al., 2005; Ding et al., 2013). The stronger AIWM was most likely related to decreasing solar activity (Solanki et al., 2004; Steinke et al., 2014a). Increasing austral summer insolation during this period should strengthen the AISM, but its effect was suppressed by the decreasing solar activity (Steinke et al., 2014a; Ardi et al., 2020). In the Sumba Strait, a change of the DOT was only indicated in its eastern part, which was DOT deepening. The deepening of DOT could be related to the intensification of surface water ITF owing to stronger AIWM (Ding et al., 2013). The intense AIWM would transfer the more saline Banda Sea waters to the southern tip of the Makassar Strait, thus displaced the freshwater plug that blocked the surface water ITF (Xu et al., 2006; Ding et al., 2013). The deepening of the DOT indicated that the effect of ITF variability could reach the Sumba Strait, even though this was only in its eastern part. The deepening of the DOT also resulted in the lower paleoproductivity (oligotrophic) condition at eastern Sumba Strait, as a thicker mix layer would inhibit the eutrophication process (Brasier, 1995) and vertical mixing was not effective 


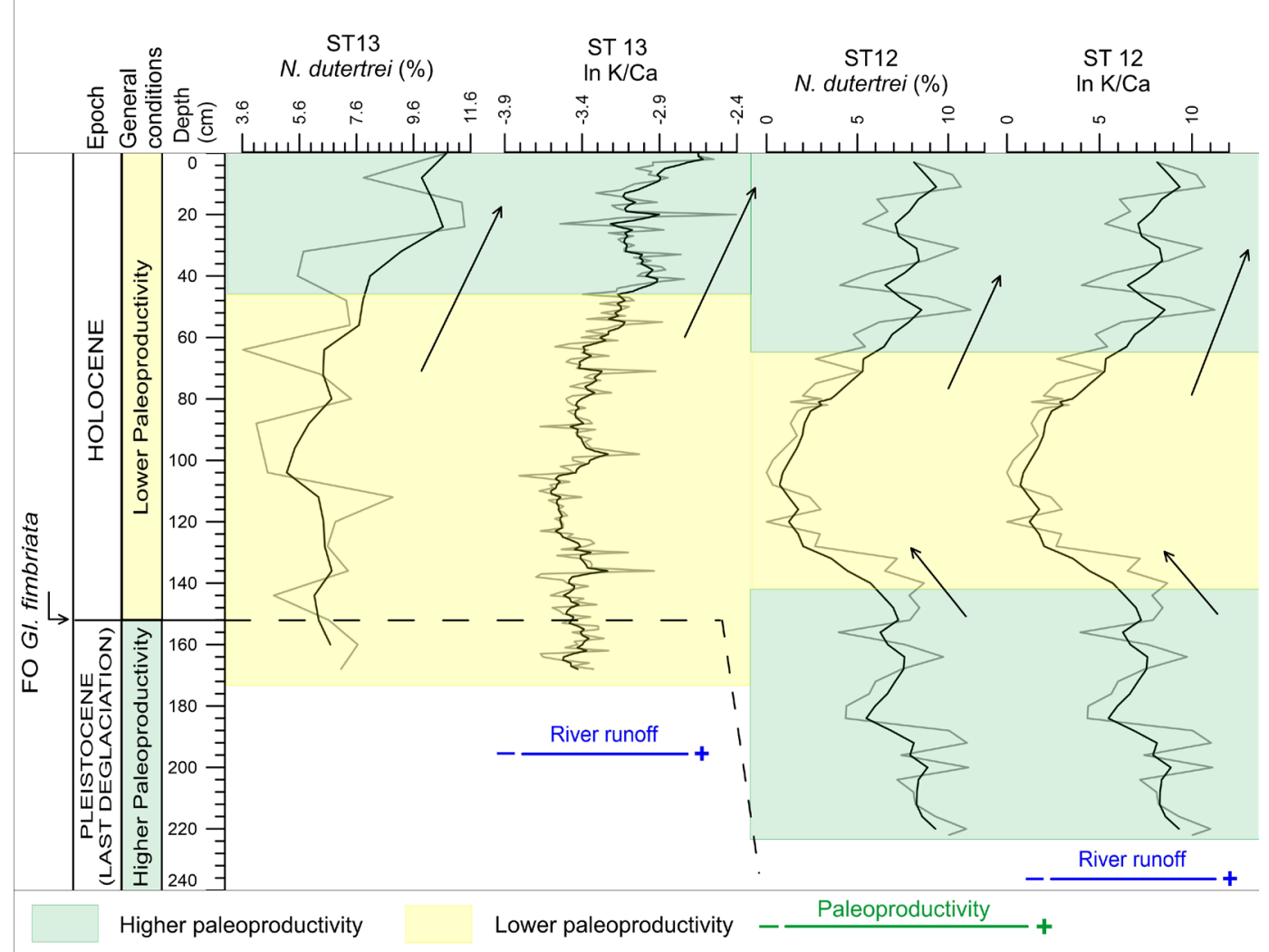

Figure 9: Plot of $N$. dutertrei abundances compared to riverine input proxy $(\ln \mathrm{K} / \mathrm{Ca})$ in central and eastern parts of Sumba Strait (core ST13 and ST12).

The dashed line indicates the FO of Gl. fimbriata (Pleistocene-Holocene boundary).

due to the narrow size of Sumba Strait (Bayhaqi et al., 2019). In central and western Sumba Strait, the effect of ITF variability was most likely counteracted by the AIWM-induced oceanographic changes, as indicated by the paleoproductivity enhancement in western Sumba Strait.

Late Holocene DOT shoaling was observed at southwestern Sumba offshore, western and central Sumba Strait while the eutrophic condition was only indicated in the central and eastern Sumba Strait. Late Holocene ENSO intensification which resulted in an El Niño-like condition (Brijker et al., 2007; Wanner et al., 2008; Chen et al., 2016) was most likely the cause for the DOT shoaling, along with the positive IOD-like condition (Abram et al., 2009; Kwiatkowski et al., 2015). Present El Niño and positive IOD years are associated with the anomalously strong southeast winds during AIWM which enhanced the coastal upwelling (Susanto et al., 2006; Ningsih et al., 2013). The relatively constant paleoproductivity at the southwest Sumba offshore and western Sumba Strait could be related to the lesser scale of upwelling enhancement compared to around the Mid Holocene and the Last Deglaciation. Despite the $E l$ Niño-like and positive IOD-like condition, which should have resulted in an enhanced AIWM condition, AISM was stronger, thus increasing the rainfall during this period (Steinke et al., 2014a; Ardi et al., 2020). Higher rainfall enhanced the river runoff, which most likely caused the increase of nutrient availability in the surface water (Kawamura et al., 2006; Steinke et al., 2014a). This mechanism explains the eutrophic conditions inferred in the central and eastern Sumba Strait which coincided with the enhancement of the riverine input proxy ( $\ln \mathrm{K} / \mathrm{Ca}$ ) (see Figure 9). This mechanism was more effective in the central and eastern Sumba Strait due to its proximity to the surrounding islands compared to the southwest Sumba offshore and the western Sumba Strait. A similar mechanism was also indicated off southwest Java during the Late Holocene, which resulted in the higher paleoproductivity condition (Setiawan et al., 2015; Xu et al., 2017). The eutrophic condition in central and eastern Sumba Strait also indicates the direct relationship of $N$. dutertrei with the freshwater influx caused by the increase of river runoff due to AISM enhancement (Mohtadi et al., 2011b; Steinke et al., 2014a), especially in a geographically-restricted sea. The cause of the DOT deepening in the eastern Sumba Strait was most likely identical to the DOT deepening that occurred around the Mid Holocene while the intensification of surface water ITF was related to the $E l$ Niño-like condition (Hendrizan et al., 2017).

The use of the relative abundance of planktonic foraminifera as a proxy to interpret the DOT and paleoproductivity has been proven effective in the southern Indo- 
nesia region (Spooner et al., 2005; Ding et al., 2013; Steinke et al., 2014b; Ardi, 2018; Ardi et al., 2019). Despite the effectiveness, the interpreted DOT and paleoproductivity from the relative abundance of planktonic foraminifera were basically qualitative. The use of geochemical proxies from both the foraminifera tests $\left(\delta^{18} \mathrm{O}, \delta^{13} \mathrm{C}, \mathrm{Mg} / \mathrm{Ca}\right.$, etc.) and bulk sediments (total organic carbon, carbonate content, etc.) is suggested to produce more plausible results in future studies. In addition, radiocarbon dating data of the Sumba Strait cores (ST12, ST13, and ST14) is needed to produce more robust geochronology and simplify the proxies comparison between the studied cores.

\section{Conclusions}

(1) DOT:

A contrast DOT pattern compared to the Timor Sea (main exit passage of ITF) during the Last DeglaciationHolocene was indicated at the Sumba Island offshore based on thermocline and mixed layer dwellers' relative abundances. This concluded that the glacial-interglacial hydrographic changes of ITF did not cause the DOT changes at Sumba Island offshore, instead, they were primarily driven by the AIM variability. The role of ENSO-like and IOD-like mechanisms to the DOT changes was only indicated around the Late Holocene. The effect of ITF changes might reach the eastern Sumba Strait, which was indicated by the shallower DOT around the Mid and Late Holocene.

(2) Paleoproductivity:

$N$. dutertrei relative abundance indicated that the monsoon-driven coastal upwelling intensification which resulted in DOT shoaling and eutrophic condition was not always the cause for the paleoproductivity enhancement. The increase of nutrient availability in surface water due to the increase of river runoff and the changes in the lifted water mass nature were also able to enhance paleoproductivity.

\section{Acknowledgement}

This research is part of the concept of sustainable coastal environmental management for eutrophication disaster mitigation research in the Priority Research and Demand Drive Research Coremap-CTI (Number: SP DIPA- 079.01.1.664156/2020). We express our gratitude to Dr. Dyah Marganingrum for the permission to participate in this research. We also thank the Research Center for Oceanography of LIPI, especially Udhi Hermawan, Ph.D. as the chief scientist of E-WIN 2016 for the permission of data usage and administrative assistance and all crews of the Baruna Jaya VIII R.V., especially Singgih Adi Wibowo for technical supports and data collecting. The Research Center for Geotechnology of LIPI and Geological Engineering Department of ITB are thanked for the laboratory facilities. We also express our grati- tude to the Indonesian Endowment Fund for Education (LPDP) (grant number: 202001110215954) for the financial assistance. Istiana, Adwi Arya, Adrianus Damanik, and Ahmad Nabil are thanked for their assistance in sample preparation and observation for core ST08, ST12, ST13, and ST14. Rizky Amalia Maulidiatsani is thanked for the assistance in proofreading.

\section{Abbreviations}

AIM: Australian-Indonesian monsoon

AISM: Australian-Indonesian summer monsoon

AIWM: Australian-Indonesian winter monsoon

AMS: Accelerator Mass Spectrometry

DOT: Depth of thermocline

E-WIN: Widya Nusantara Expedition

FO: First occurence

ENSO: El Niño Southern Oscillation

HPD: High Probability Density

IOD: Indian Ocean Dipole

ITB: Institut Teknologi Bandung

ITCZ: Inter-tropical Convergence Zone

ITF: Indonesian Through-flow

KSTF: Kalimantan Strait Through-flow

LC: Leeuwin Current

LIPI: Indonesian Institute of Sciences

NPIW: North Pacific Intermediate Water

SEC: South Equatorial Current

SJC: South Java Current

\section{References}

\section{Papers:}

Abram, N. J., McGregor, H. V., Gagan, M. K., Hantoro, W. S., and Suwargadi, B. W. (2009): Oscillations in the southern extent of the Indo-Pacific Warm Pool during the mid-Holocene. Quaternary Science Reviews, 28(25-26), 27942803. https://doi.org/10.1016/j.quascirev.2009.07.006

Aldrian, E., and Susanto, R. D. (2003): Identification of three dominant rainfall regions within Indonesia and their relationship to sea surface temperature, International Journal of Climatology, 23(12), 1435-1452. https://doi.org/10. 1002/joc. 950

Andruleit, H., Lückge, A., Wiedicke, M., and Stäger, S. (2008): Late Quaternary development of the Java upwelling system (eastern Indian Ocean) as revealed by coccolithophores. Marine Micropaleontology, 69(1), 3-15. https:// doi.org/10.1016/j.marmicro.2007.11.005

Ardi, R. D. W., Aswan, Maryunani, K. A., Yulianto, E., Putra, P. S., Nugroho, S. H., and Istiana (2020): Last Deglaciation-Holocene Australian-Indonesian Monsoon Rainfall Changes Off Southwest Sumba, Indonesia. Atmosphere, 11(9), 932. https://doi.org/10.3390/atmos11090932

Barmawidjaja, B. M., Rohling, E. J., van der Kaars, W. A., Vergnaud Grazzini, C., and Zachariasse, W. J. (1993): Gla- 
cial conditions in the northern Molucca Sea region (Indonesia). Palaeogeography, Palaeoclimatology, Palaeoecology, 101(1-2), 147-167. https://doi.org/10.1016/0031-0182 (93)90157-E

Bayhaqi, A., Lenn, Y.-D., Surinati, D., Polton, J., Nur, M., Corvianawatie, C., and Purwandana, A. (2019): The Variability of Indonesian Throughflow in Sumba Strait and Its Linkage to the Climate Events. American Journal of Applied Sciences, 16(4), 118-133. https://doi.org/10.3844/ ajassp.2019.118.133

Bé, A. W. H., Hutson, W. H., and Be, A. W. H. (1977): Ecology of Planktonic Foraminifera and Biogeographic Patterns of Life and Fossil Assemblages in the Indian Ocean. Micropaleontology, 23(4), 369. https://doi.org/10.2307/1485406

Blaauw, M. (2010): Methods and code for 'classical' age-modelling of radiocarbon sequences. Quaternary Geochronology, 5(5), 512-518. https://doi.org/10.1016/j.quageo.2010. 01.002

Brasier, M. D. (1995): Fossil indicators of nutrient levels. 1: eutrophication and climate change. Marine Palaeoenvironmental Analysis from Fossils, (83), 113-132.

Brijker, J. M., Jung, S. J. A., Ganssen, G. M., Bickert, T., and Kroon, D. (2007): ENSO related decadal scale climate variability from the Indo-Pacific Warm Pool. Earth and Planetary Science Letters, 253(1-2), 67-82. https://doi. org/10.1016/j.epsl.2006.10.017

Bronk Ramsey, C. (2009): Bayesian Analysis of Radiocarbon Dates. Radiocarbon, 51(1), 337-360. https://doi.org/10. 1017/s0033822200033865

Capelli, E. L. G., Holbourn, A., Kuhnt, W., and Regenberg, M. (2016): Changes in Timor Strait hydrology and thermocline structure during the past $130 \mathrm{ka}$. Palaeogeography, Palaeoclimatology, Palaeoecology. https://doi.org/10.1016 /j.palaeo.2016.09.010

Chen, G., Han, W., Li, Y., and Wang, D. (2016): Interannual variability of equatorial eastern Indian Ocean upwelling: Local versus remote forcing. Journal of Physical Oceanography, 46(3), 789-807. https://doi.org/10.1175/JPOD-15-0117.1

Chen, S., Hoffmann, S. S., Lund, D. C., Cobb, K. M., Emilegeay, J., and Adkins, J. F. (2016): A high-resolution speleothem record of western equatorial Pacific rainfall : Implications for Holocene ENSO evolution. Earth and Planetary Science Letters, 442, 61-71. https://doi.org/10.1016/j.epsl. 2016.02.050

Deplazes, G., Lückge, A., Peterson, L. C., Timmermann, A., Hamann, Y., Hughen, K. A., Röhl, U., Laj, C., Cane, M. A., Sigman, D. M., and Haug, G. H. (2013): Links between tropical rainfall and North Atlantic climate during the last glacial period. Nature Geoscience, 6(3), 213-217. https:// doi.org/10.1038/ngeo1712

Ding, X., Bassinot, F., Guichard, F., and Fang, N. Q. (2013): Indonesian Throughflow and monsoon activity records in the Timor Sea since the last glacial maximum. Marine Micropaleontology, 101, 115-126. https://doi.org/10.1016/j. marmicro.2013.02.003

Feng, M., Zhang, N., Liu, Q., and Wijffels, S. (2018): The Indonesian throughflow, its variability and centennial change. Geoscience Letters, 5(1). https://doi.org/10.1186/ s40562-018-0102-2

Gibbons, F. T., Oppo, D. W., Mohtadi, M., Rosenthal, Y., Cheng, J., Liu, Z., and Linsley, B. K. (2014): Deglacial $\delta 18 \mathrm{O}$ and hydrologic variability in the tropical Pacific and Indian Oceans. Earth and Planetary Science Letters, 387, 240-251. https://doi.org/10.1016/j.epsl.2013.11.032

Gordon, A. L. (2005): Oceanography of the Indonesian Seas and Their Throughflow. Oceanography, 18(4), 13-13. https://doi.org/10.5670/oceanog.2005.18

Gordon, A. L., and Fine, R. A. (1996): Pathways of water between the Pacific and Indian oceans in the Indonesian seas. Nature. https://doi.org/10.1038/379146a0

Gordon, A. L., Susanto, R. D., and Vranes, K. (2003): Cool Indonesian throughflow as a consequence of restricted surface layer flow. Nature, 425(6960), 824-828. https://doi. org/10.1038/nature02038

Hendrawan, I. G., Asai, K., Triwahyuni, A., and Lestari, D. V. (2019): The interanual rainfall variability in Indonesia corresponding to El Niño Southern Oscillation and Indian Ocean Dipole. Acta Oceanologica Sinica, 38(7), 57-66. https://doi.org/10.1007/s13131-019-1457-1

Hendrizan, M., Kuhnt, W., and Holbourn, A. (2017): Variability of Indonesian Throughflow and Borneo Runoff During the Last 14 kyr. Paleoceanography, 32(10), 1054-1069. https://doi.org/10.1002/2016PA003030

Holbourn, A., Kuhnt, W., Kawamura, H., Jian, Z., Grootes, P., Erlenkeuser, H., and Xu, J. (2005): Orbitally paced paleoproductivity variations in the Timor Sea and Indonesian throughflow variability during the last 460 kyr. Paleoceanography,20(3),1-18.https://doi.org/10.1029/2004PA001094

Holbourn, A., Kuhnt, W., and Xu, J. (2011): Indonesian Throughflow variability during the last $140 \mathrm{ka}$ : The timor sea outflow, Geological Society Special Publication, 355, 283-303. https://doi.org/10.1144/SP355.14

Huang, E., Tian, J., and Liu, J. (2015): Dynamics of the Australian-Indonesian monsoon across Termination II: Implications of molecular-biomarker reconstructions from the Timor Sea. Palaeogeography, Palaeoclimatology, Palaeoecology, 423, 32-43. https://doi.org/10.1016/j.palaeo. 2015.01.027

Ishiwa, T., Yokoyama, Y., Reuning, L., McHugh, C. M., De Vleeschouwer, D., and Gallagher, S. J. (2019): Australian Summer Monsoon variability in the past 14,000 years revealed by IODP Expedition 356 sediments. Progress in Earth and Planetary Science, 6(1). https://doi.org/10.1186/ s40645-019-0262-5

Kawamura, H., Holbourn, A., and Kuhnt, W. (2006): Climate variability and land-ocean interactions in the Indo Pacific Warm Pool: A 460-ka palynological and organic geochemical record from the Timor Sea. Marine Micropaleontology, 59(1), 1-14. https://doi.org/10.1016/j.marmicro. 2005.09.001

Kenneth, J. P., and Srinivasan, M. S. (1983): Neogene planktonic foraminifera: A phylogenetic atlas. The Journal of Foraminiferal Research, Hutchinson and Ross, Stroudburg, Pennsylvania, 160-125.

Kuhnt, W., Holbourn, A., Hall, R., Zuvela, M., and Käse, R. (2004): Neogene history of the indonesian throughflow, 
299-320 in Geophysical Monograph Series. https://doi. org/10.1029/149GM16

Kuhnt, W., Holbourn, A., Xu, J., Opdyke, B., Deckker, P. De, and Mudelsee, M. (2015): Southern Hemisphere control on Australian monsoon variability during the late deglaciation and Holocene. https://doi.org/10.1038/ncomms6916

Kusuma, D. W., Murdimanto, A., Aden, L. Y., Sukresno, B., Jatisworo, D., and Hanintyo, R. (2017): Sea Surface Temperature Dynamics in Indonesia. IOP Conference Series: Earth and Environmental Science, 98(1). https://doi. org/10.1088/1755-1315/98/1/012038

Kwiatkowski, C., Prange, M., Varma, V., Steinke, S., Hebbeln, D., and Mohtadi, M. (2015): Holocene variations of thermocline conditions in the eastern tropical Indian Ocean, Quaternary Science Reviews, 114, 33-42. https://doi. org/10.1016/j.quascirev.2015.01.028

Lana, A. B., Kurniawati, N., Purba, N. P., and Syamsuddin, M. L. (2017): Thermocline Layers Depth and Thickness in Indonesian Waters when Souteast Monsoon. Omni-Akuatika, 13(2), 65-72. https://doi.org/10.20884/1.oa.2017.13.2.70

Levi, C., Labeyrie, L., Bassinot, F., Guichard, F., Cortijo, E., Waelbroeck, C., Caillon, N., Duprat, J., de Garidel-Thoron, T., and Elderfield, H. (2007): Low-latitude hydrological cycle and rapid climate changes during the last deglaciation. Geochemistry, Geophysics, Geosystems, 8(5), 1-11. https://doi.org/10.1029/2006GC001514

Lückge, A., Mohtadi, M., Rühlemann, C., Scheeder, G., Vink, A., Reinhardt, L., and Wiedicke, M. (2009): Monsoon versus ocean circulation controls on paleoenvironmental conditions off southern Sumatra during the past 300,000 years. Paleoceanography, 24(1). https://doi.org/10.1029 /2008PA001627

Lynch-Stieglitz, J., Schmidt, M. W., Gene Henry, L., Curry, W. B., Skinner, L. C., Mulitza, S., Zhang, R., and Chang, P. (2014): Muted change in Atlantic overturning circulation over some glacial-aged Heinrich events. Nature Geoscience, 7(2), 144-150. https://doi.org/10.1038/ngeo2045

Martínez, J. I., De Deckker, P., and Barrows, T. T. (1999): Palaeoceanography of the last glacial maximum in the eastern Indian Ocean: Planktonic foraminiferal evidence. Palaeogeography, Palaeoclimatology, Palaeoecology, 147(1-2), 73-99. https://doi.org/10.1016/S0031-0182(98)00153-9

Mohtadi, M., Max, L., Hebbeln, D., Baumgart, A., Krück, N., and Jennerjahn, T. (2007): Modern environmental conditions recorded in surface sediment samples off $\mathrm{W}$ and SW Indonesia: Planktonic foraminifera and biogenic compounds analyses. Marine Micropaleontology, 65(1-2), 96-112. https://doi.org/10.1016/j.marmicro.2007.06.004

Mohtadi, M., Oppo, D. W., Lückge, A., DePol-Holz, R., Steinke, S., Groeneveld, J., Hemme, N., and Hebbeln, D. (2011a): Reconstructing the thermal structure of the upper ocean: Insights from planktic foraminifera shell chemistry and alkenones in modern sediments of the tropical eastern Indian Ocean. Paleoceanography, 26(3), n/a-n/a. https:// doi.org/10.1029/2011PA002132

Mohtadi, M., Oppo, D. W., Steinke, S., Stuut, J. B. W., De PolHolz, R., Hebbeln, D., and Lückge, A. (2011b): Glacial to Holocene swings of the Australian-Indonesian monsoon.
Nature Geoscience, 4(8), 540-544. https://doi.org/10.1038/ ngeo1209

Mohtadi, M., Prange, M., and Steinke, S. (2016): Palaeoclimatic insights into forcing and response of monsoon rainfall. Nature, 533(7602), 191-199. https://doi.org/10.1038/ nature 17450

Müller, A., and Opdyke, B. N. (2000): Glacial-interglacial changes in nutrient utilization and paleoproductivity in the Indonesian Throughflow sensitive Timor Trough, easternmost Indian Ocean. Paleoceanography, 15(1), 85-94. https://doi.org/10.1029/1999PA900046

Ningsih, N. S., Rakhmaputeri, N., and Harto, A. B. (2013): Upwelling variability along the southern coast of Bali and in Nusa Tenggara waters. Ocean Science Journal, 48(1), 49-57. https://doi.org/10.1007/s12601-013-0004-3

Potemra, J. T., Sprintall, J., Hautala, S. L., and Pandoe, W. (2003): Observed estimates of convergence in the Savu Sea, Indonesia. Journal of Geophysical Research C: Oceans, 108(1), 1-1.https://doi.org/10.1029/2002jc001507

Putra, P. S., and Nugroho, S. H. (2020): Holocene Climate Dynamics in Sumba Strait, Indonesia: A Preliminary Evidence From High Resolution Geochemical Records and Planktonic Foraminifera, Studia Quartenaria, 32(2), 9199. https://doi.org/10.24425/sq.2020.133753

Qu, T., Du, Y., Strachan, J., Meyers, G., and Slingo, J. (2005): Sea Surface Temperature and Its Variability in the Indonesian Region. Oceanography, 18(4), 50-61. https://doi. org/10.5670/oceanog.2005.05

Ravelo, A. C., Fairbanks, R. G., and Philander, S. G. H. (1990): Reconstructing Tropical Atlantic hydrography using planktonic foraminifera and an ocean model. Paleoceanography, 5(3), 409-431.

Reimer, P. J., Edouard Bard, B., Alex Bayliss, B., Warren Beck, B. J., Paul Blackwell, B. G., and Christopher Bronk Ramsey, B. (2013): Intcal13 and Marine13 Radiocarbon Age Calibration Curves 0-50,000 Years Cal Bp. Radiocarbon, 55(4), 1869-1887. https://doi.org/10.1017/S0033822 200048864

Schott, F. A., and McCreary, J. P. (2001): The monsoon circulation of the Indian Ocean. Progress in Oceanography, 51(1), 1-123. https://doi.org/10.1016/S0079-6611(01)00083-0

Setiawan, R. Y., Mohtadi, M., Southon, J., Groeneveld, J., Steinke, S., and Hebbeln, D. (2015): The consequences of opening the Sunda Strait on the hydrography of the eastern tropical Indian Ocean. Paleoceanography, 30(10), 13581372. https://doi.org/10.1002/2015PA002802

Solanki, S. K., Usoskin, I. G., Kromer, B., Schüssler, M., and Beer, J. (2004): Unusual activity of the Sun during recent decades compared to the previous 11,000 years. Nature, 431 (7012), 1084-1087. https://doi.org/10.1038/nature02995

Spooner, M. I., Barrows, T. T., De Deckker, P., and Paterne, M. (2005): Palaeoceanography of the Banda Sea, and Late Pleistocene initiation of the Northwest Monsoon. Global and Planetary Change, 49(1-2), 28-46. https://doi.org/ 10.1016/j.gloplacha.2005.05.002

Sprintall, J., Potemra, J. T., Hautala, S. L., Bray, N. A., and Pandoe, W. W. (2003): Temperature and salinity variability in the exit passages of the Indonesian Throughflow. Deep- 
Sea Research Part II: Topical Studies in Oceanography, 50(12-13), 2183-2204. https://doi.org/10.1016/S09670645(03)00052-3

Sprintall, J., and Révelard, A. (2014): The Indonesian Throughflow response to Indo-Pacific climate variability. Journal of Geophysical Research: Oceans, 119(2), 1161-1175. https://doi.org/10.1002/2013JC009533

Sprintall, J., Wijffels, S. E., Molcard, R., and Jaya, I. (2009): Direct estimates of the indonesian throughflow entering the indian ocean: 2004-2006. Journal of Geophysical Research: Oceans, 114(7), 2004-2006. https://doi.org/10. 1029/2008JC005257

Steinke, S., Mohtadi, M., Prange, M., Varma, V., Pittauerova, D., and Fischer, H. W. (2014a): Mid- to Late-Holocene Australian-Indonesian summer monsoon variability. Quaternary Science Reviews, 93, 142-154. https://doi.org/ 10.1016/j.quascirev.2014.04.006

Steinke, S., Prange, M., Feist, C., Groeneveld, J., and Mohtadi, M. (2014b): Upwelling variability off southern Indonesia over the past two millennia. Geophysical Research Letters, 41(21), 7684-7693. https://doi.org/10.1002/2014GL061450

Susanto, R. D., Gordon, A. L., and Zheng, Q. (2001): Upwelling along the coasts of Java and Sumatra and its relation to ENSO. Geophysical Research Letters, 28(8), 15991602. https://doi.org/10.1029/2000GL011844

Susanto, R. D., Moore, T. S., and Marra, J. (2006): Ocean color variability in the Indonesian Seas during the SeaWiFS era. Geochemistry, Geophysics, Geosystems, 7(5), 1-16. https://doi.org/10.1029/2005GC001009

Talma, A. S., and Vogel, J. C. (1993): A simplified approach to calibrating 14C dates. Radiocarbon, 35(2), 317-322. https://doi.org/10.1017/S0033822200065000

Wang, P. X., Wang, B., Cheng, H., Fasullo, J., Guo, Z., and Kiefer, T. (2017): Earth-Science Reviews The global monsoon across time scales : Mechanisms and outstanding issues, Earth-Science Reviews, 174(July 2016), 84-121. https://doi.org/10.1016/j.earscirev.2017.07.006

Wanner, H., Beer, J., Bütikofer, J., Crowley, T. J., Cubasch, U., Flückiger, J., Goosse, H., Grosjean, M., Joos, F., Kaplan, J. O., Küttel, M., Müller, S. A., Prentice, I. C., Solomina, O., Stocker, T. F., Tarasov, P., Wagner, M., and Widmann, M. (2008): Mid- to Late Holocene climate change: an overview. Quaternary Science Reviews, 27(19-20), 17911828. https://doi.org/10.1016/j.quascirev.2008.06.013

Wheeler, M. C., and McBride, J. L. (2005): Australian-Indonesian monsoon, 125-173 in Intraseasonal Variability in the Atmosphere-Ocean Climate System, Springer Berlin Heidelberg, Berlin, Heidelberg. https://doi.org/10.1007/3540-27250-X_5

Wyrwoll, K. H., and Miller, G. H. (2001): Initiation of the Australian summer monsoon 14,000 years ago. Quaternary International, 82(85), 119-128. https://doi.org/10. 1016/S1040-6182(01)00034-9

$\mathrm{Xu}$, J. (2014): Change of Indonesian Throughflow outflow in response to East Asian monsoon and ENSO activities since the Last Glacial. Science China Earth Sciences, 57(4), 791-801. https://doi.org/10.1007/s11430-014-4845-0

Xu, J., Holbourn, A., Kuhnt, W., Jian, Z., and Kawamura, H. (2008): Changes in the thermocline structure of the Indo- nesian out fl ow during Terminations I and II. Earth and Planetary Science Letters 273, 152-162. https://doi.org/ 10.1016/j.eps1.2008.06.029

Xu, J., Kuhnt, W., Holbourn, A., Andersen, N., and Bartoli, G. (2006): Changes in the vertical profile of Indonesian Throughflow during Termination II: Evidence from the Timor Sea. Paleoceanography, 21(4), 1-14. https://doi. org/10.1029/2006PA001278

Xu, Y., Wang, L., Yin, X., Ye, X., Li, D., Liu, S., Shi, X., Troa, R. A., Zuraida, R., Triarso, E., and Hendrizan, M. (2017): The influence of the Sunda Strait opening on paleoenvironmental changes in the eastern Indian Ocean. Journal of Asian Earth Sciences, 146, 402-411. https://doi.org/ 10.1016/j.jseaes.2017.06.014

Yim, S. Y., Wang, B., Liu, J., and Wu, Z. (2014): A comparison of regional monsoon variability using monsoon indices. Climate Dynamics, 43(5-6), 1423-1437. https://doi.org/ 10.1007/s00382-013-1956-9

Zhang, P., Zuraida, R., Rosenthal, Y., Holbourn, A., Kuhnt, W., and $\mathrm{Xu}, \mathrm{J}$. (2019): Geochemical characteristics from tests of four modern planktonic foraminiferal species in the Indonesian Throughflow region and their implications. Geoscience Frontiers, 10(2), 505-516. https://doi.org/10.1016 /j.gsf.2018.01.011

Zhang, P., Zuraida, R., Xu, J., and Yang, C. (2016): Stable carbon and oxygen isotopes of four planktonic foraminiferal species from core-top sediments of the Indonesian throughflow region and their significance. Acta Oceanologica Sinica, 35(10), 63-75. https://doi.org/10.1007/s13131-0160890-1

\section{Papers written in non-English language:}

Ardi, R. D. W., Maryunani, K. A., Yulianto, E., Putra, P. S., Nugroho, S. H. (2019): Biostratigrafi dan analisis perubahan kedalaman termoklin di lepas pantai barat daya Sumba sejak Pleistosen Akhir berdasarkan kumpulan foraminifera planktonik (Biostratigraphy and analysis of changes in thermocline depth off the Southwest Coast of Sumba since the Late Pleistocene based on planktonic foraminifera assemblages). Buletin Geologi, 3(2), 355-362. https://doi. org/10.5614/bull.geol.2019.3.2.3. (in Indonesian with English Abstract)

Damanik, A., Putra, P. S., Nugroho, S. H., Kapid, R. (2019): Hubungan vertikal antara kelimpahan foraminifera dan karakteristik sedimen inti di Selat Sumba, Nusa Tenggara Timur (The vertical relationship between foraminiferal abundance and characterisitics of core sediment in Sumba Strait, East Nusa Tenggara). Jurnal Geologi Kelautan, 17(1), 19-32. https://doi.org/10.32693/jgk.17.1.2019.563. (in Indonesian with English Abstract)

\section{Chapters in books or proceedings with editor(s):}

Bolli, H. M., Saunders, J. B. (1985). Oligocene to Holocene low latitude planktic foraminifera. In H. M. Bolli, J. B. Saunders, \& K. Perch-Nielsen (Eds.): Plankton Stratigraphy 1st edition. - New York: Cambridge University Press, 155-262, $1032 \mathrm{p}$. 
Tomczak, M., and Godfrey, J. S. (2003): Adjacent seas of the Indian Ocean and the Australasian Mediterranian Sea (The Indonesian Throughflow) (pdf version), 215-228 in Regional Oceanography: An Introduction, Daya Publishing House, Delhi.

\section{Books/thesis:}

Maryunani (2009): Microfossil approach based on Cendrawasih Bay data, to interpreting and reconstructing Equatorial Western Pacific paleoclimate since Last Glacial (Late Pleistocene). Institut Teknologi Bandung, $141 \mathrm{pp}$.

\section{Books/thesis written in non-English language:}

Ardi, R. D. W. (2018): Rekonstruksi paleoklimatologi dan palo-oseanografi sejak Pleistosen Akhir berdasarkan kumpulan foraminifera di lepas pantai barat daya Sumba, Nusa Tenggara Timur (Paleoclimatology and paleo-oceanogra- phy reconstruction since Late Pleistocene based on foraminiferal assemblages off the southwest coast of Sumba Island), East Nusa Tenggara. Institut Teknologi Bandung, 65 pp. (in Indonesian with English Abstract)

\section{Internet sources:}

GEBCO Bathymetric Compilation Group 2020 (2020): GEBCO_2020 Grid. URL: https://www.gebco.net/data_and products/gridded_bathymetry_data (accessed $22^{\text {nd }}$ July 2020)

Blaauw, M. (2020): clam: Classical Age-Depth Modelling of Cores from Deposits. $\mathrm{R}$ package version 2.3.4. URL: http://cran.r-project.org/package= clam (accessed $24^{\text {th }} \mathrm{Au}-$ gust 2020)

R Core Team. (2013). R: A language and environment for statistical computing. Vienna, Austria: R Foundation for Statistical Computing. URL: http://www.r-project.org (accessed $21^{\text {st }}$ August 2020)

\section{SAŽETAK}

\section{Dubina promjene termoklina na otoku Sumba na temelju planktonskih sklopova foraminifera i njegove implikacije na eutrofikaciju od posljednje deglacijacije ( 18 ka BP): preliminarna studija}

Područje ispitivanja nalazi se uz otok Sumba, a promjene dubine termokline (DOT) u ovoj regiji nisu dobro poznate u usporedbi s Timorskim morem. Zajednice planktonskih foraminifera korištene su za prepoznavanje DOT-a i promjene paleoproduktivnosti u jezgrama prikupljenim s jugozapadne Sumbe (STo8) i iz tjesnaca Sumba (ST12, ST13 i ST14). Ova studija sugerira da su tisućljetne promjene u režimu australsko-indonezijskoga monsuna (AIM) bile glavni čimbenik DOT promjena na jugozapadu Sumbe i tjesnaca Sumba nakon posljednje deglacijacije, što je stvorilo suprotne uvjete $u$ odnosu na Timorsko more. Učinak poput južnih oscilacija El Niño (ENSO) i dipola Indijskoga oceana (IOD) sličnih DOT promjenama naznačen je samo oko kasnoga holocena, dok su promjene indonezijskoga protoka (ITF) utjecale samo na istočni tjesnac Sumba oko srednjega i kasnoga holocena. Produbljavanje termokline usko je povezano s poboljšanjem AIWM (AISM), El Niñom (La Niñom) i pozitivnim (negativnim) IOD-om. Poboljšanje paleoproduktivnosti nije bilo povezano samo s jačanjem DOT-a, već i s većom dostupnošću hranjivih sastojaka zbog povećanoga donosa slatke vode rijekama. Promjene u prirodi podignute vodene mase također su utjecale na promjene u paleoproduktivnosti.

\section{Ključne riječi:}

australsko-indonezijski monsun, primijenjena mikropaleontologija, indonezijski protok, Mali Sundski otoci, paleoceanografija

\section{Author's contribution}

Ryan Dwi Wahyu Ardi (1) (M. Sc., intern researcher, doctoral candidate, applied micropaleontologist, quarternary geologist) as the main contributor provided the micropaleontological analysis, paleoenvironmental interpretation, agedepth modeling, and presentation of the results. Aswan (2) (Dr., associate professor, quarternary geologist, paleontologist) provided the paleoenvironmental interpretation and presentation of the results. Khoiril Anwar Maryunani (3) (Dr., assistant professor, applied micropaleontologist, paleoclimatologist, paleoceanographer) provided paleoenvironmental interpretation and paleoclimatological and paleoceanographic views. Eko Yulianto (4) (Dr., senior researcher, quarternary geologist, paleoclimatologist) provided the paleoenvironmental interpretation and administered the research. Purna Sulastya Putra (5) (M. Sc., senior researcher, doctoral candidate, quarternary geologist, marine geologist) performed fieldwork and provided the regional marine geology view. Septriono Hari Nugroho (6) (M. Sc., junior researcher, doctoral candidate, quarternary geologist, marine geologist) performed the fieldwork and provided the regional marine geology view. 


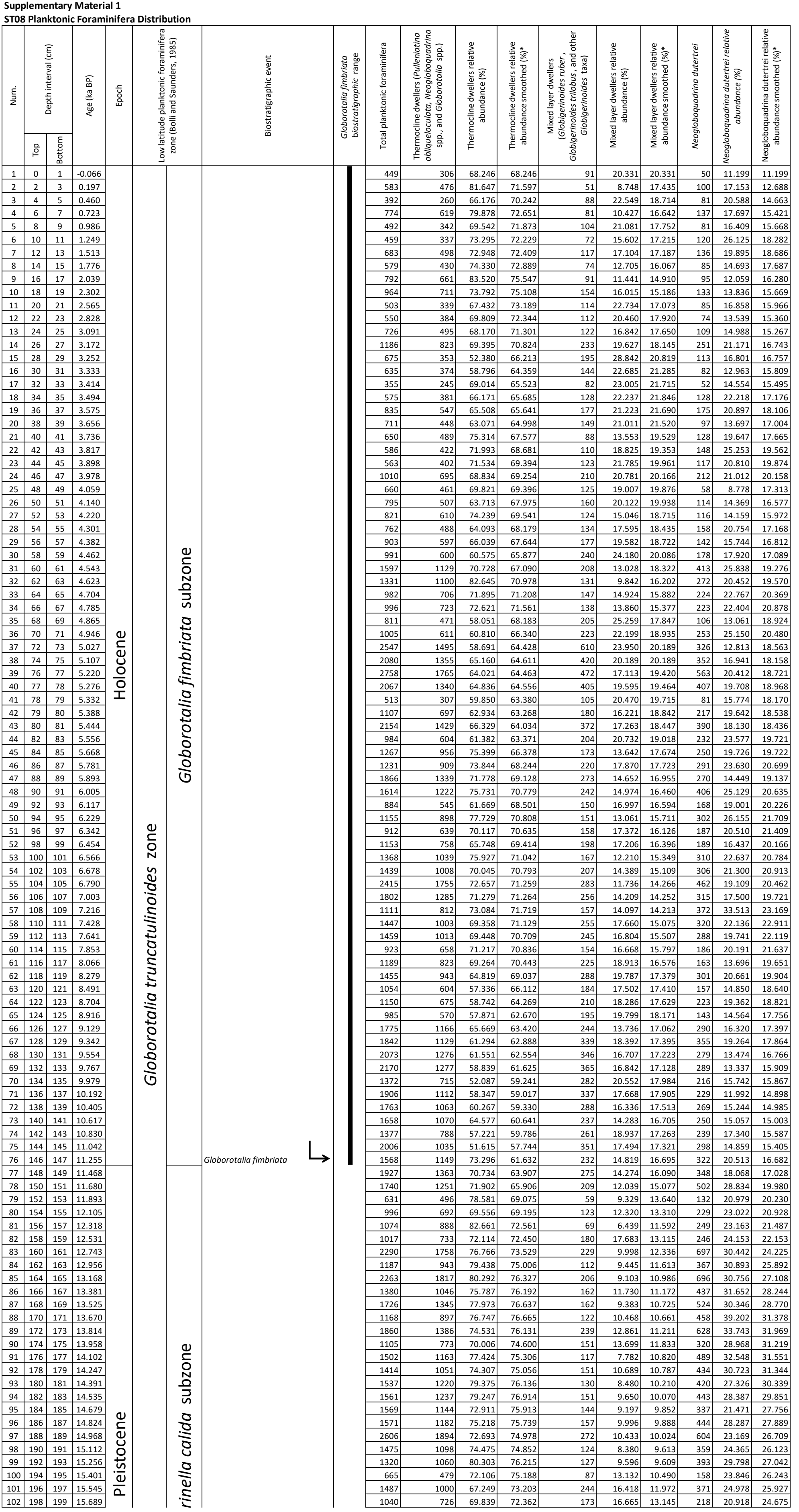




\begin{tabular}{|c|c|c|c|c|c|c|c|c|c|c|c|c|c|c|c|}
\hline 103 & 200 & 201 & \begin{tabular}{|l|l}
15.833 \\
\end{tabular} & & \multirow{18}{*}{$\begin{array}{l}\text { Globorotalia truncatulinoides, } \\
\text { Globogerinella calida }\end{array}$} & 1902 & \begin{tabular}{|l|l|}
1549 \\
\end{tabular} & 81.434 & 74.630 & \begin{tabular}{|c|}
179 \\
\end{tabular} & \begin{tabular}{|l|l|}
9.391 \\
\end{tabular} & 12.207 & 553 & 29.056 & 25.770 \\
\hline 104 & 202 & 203 & 15.978 & & & 2133 & 1775 & 83.216 & 76.777 & 164 & 7.700 & 11.080 & 588 & 27.543 & 26.213 \\
\hline 105 & 204 & 205 & 16.122 & & & 2478 & 2011 & 81.157 & 77.872 & 237 & \begin{tabular}{|l|l|}
9.543 \\
\end{tabular} & 10.696 & 880 & 35.506 & 28.537 \\
\hline 106 & 206 & 207 & 16.266 & & & 3918 & 3113 & 79.460 & 78.269 & 458 & 11.680 & 10.942 & 1328 & 33.900 & 29.878 \\
\hline 107 & \begin{tabular}{|l|}
208 \\
\end{tabular} & 209 & $\mid 16.410$ & & & 2414 & 1869 & 77.430 & 78.059 & 290 & 12.025 & 11.213 & 749 & 31.032 & 30.166 \\
\hline 108 & 210 & 211 & 16.555 & & & 1314 & 931 & 70.850 & 76.257 & 259 & 19.670 & 13.327 & 439 & 33.429 & 30.982 \\
\hline 109 & 212 & 213 & 16.699 & & & 1674 & 1216 & 72.657 & 75.357 & 246 & \begin{tabular}{|c|}
14.717 \\
\end{tabular} & 13.674 & 513 & 30.662 & 30.902 \\
\hline 110 & 214 & 215 & 16.843 & & & 2466 & 2015 & 81.681 & 76.938 & 154 & 6.247 & 11.818 & 1042 & 42.249 & 33.739 \\
\hline 111 & 216 & 217 & 16.988 & & & 1949 & 1626 & 83.443 & 78.564 & 145 & 7.436 & 10.722 & 603 & 30.946 & 33.041 \\
\hline 112 & 218 & 219 & 17.132 & & & 2273 & 1872 & 82.343 & 79.509 & 167 & 7.364 & 9.883 & \begin{tabular}{ll|}
619 \\
\end{tabular} & 27.226 & 31.587 \\
\hline 113 & 220 & 221 & 17.276 & & & 2879 & 2576 & 89.483 & 82.003 & 91 & \begin{tabular}{|l|l|}
3.148 \\
\end{tabular} & 8.199 & 1051 & 36.495 & 32.814 \\
\hline 114 & \begin{tabular}{|l|}
222 \\
\end{tabular} & 223 & 17.420 & & & 3220 & 2836 & 88.073 & 83.520 & 209 & 6.476 & 7.768 & 1120 & 34.778 & 33.305 \\
\hline 115 & \begin{tabular}{|l|}
224 \\
\end{tabular} & 225 & 17.565 & & & 3352 & 2701 & 80.572 & 82.783 & 423 & 12.610 & 8.979 & 1371 & 40.910 & 35.206 \\
\hline 116 & 226 & 227 & 17.709 & & & 17761 & 1396 & 79.286 & 81.909 & 140 & 7.964 & 8.725 & 730 & 41.436 & 36.764 \\
\hline 117 & 228 & 229 & 17.853 & & & 3070 & 2489 & 81.073 & 81.700 & 314 & 10.240 & 9.104 & 1194 & 38.882 & 37.293 \\
\hline 118 & 230 & 231 & \begin{tabular}{|l|l}
17.997 \\
\end{tabular} & & & 1510 & 1221 & 80.866 & 81.492 & 118 & 7.784 & 8.774 & 650 & 43.034 & 38.729 \\
\hline 119 & 232 & 233 & \begin{tabular}{|l}
18.142 \\
\end{tabular} & & & 2561 & 2227 & 86.982 & 82.864 & \begin{tabular}{|l|}
173 \\
\end{tabular} & 6.766 & 8.272 & \begin{tabular}{|l|l}
928 \\
\end{tabular} & 36.242 & 38.107 \\
\hline 120 & \begin{tabular}{|l|}
234 \\
\end{tabular} & 235 & 18.286 & & & 5912 & 5072 & 85.787 & & 488 & 8.257 & & 2633 & 44.543 & \\
\hline
\end{tabular}
Globogerinella calida

First Occurrence

Occurrence 
Supplementary Material 2

ST12 Planktonic Foraminifera Distribution

\begin{tabular}{|c|c|c|c|c|c|c|c|c|c|c|c|c|c|c|c|c|c|}
\hline छे & \multicolumn{2}{|c|}{ 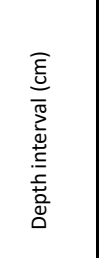 } & 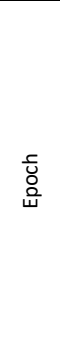 & \multicolumn{2}{|c|}{ 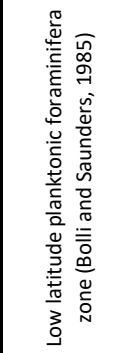 } & 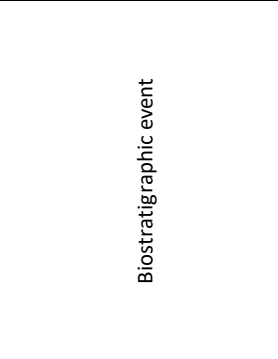 & 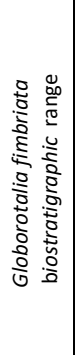 & 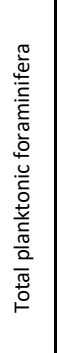 & 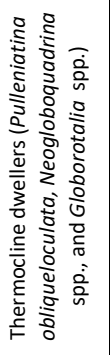 & 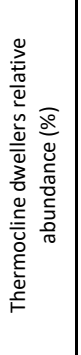 & 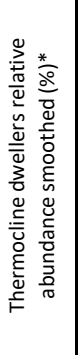 & 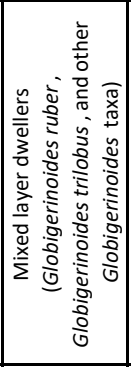 & 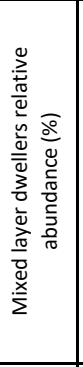 & 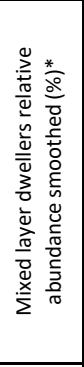 & 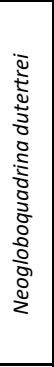 & 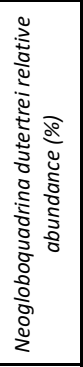 & 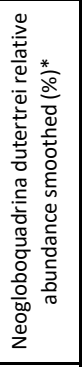 \\
\hline 1 & 3 & 4 & & & & & & 308 & 223 & 72.403 & \begin{tabular}{|l|l|}
72.403 \\
\end{tabular} & 55 & 24.664 & 24.664 & 25 & 8.117 & 8.117 \\
\hline 2 & 7 & 8 & & & & & & 303 & 238 & 78.548 & 74.246 & 48 & 20.168 & 23.315 & 31 & 10.231 & 8.751 \\
\hline 3 & 11 & 12 & & & & & & 299 & 234 & 78.261 & 75.451 & 48 & 20.513 & 22.474 & 32 & 10.702 & 9.336 \\
\hline 4 & 15 & 16 & & & & & & 296 & 223 & 75.338 & 75.417 & 44 & \begin{tabular}{|c|}
19.731 \\
\end{tabular} & 21.651 & 18 & 6.081 & 8.360 \\
\hline 5 & 19 & 20 & & & & & & 300 & 238 & 79.333 & 76.592 & 41 & 17.227 & 20.324 & 20 & 6.667 & 7.852 \\
\hline 6 & 23 & 24 & & & & & & 302 & 246 & 81.457 & 78.051 & 33 & 13.415 & 18.251 & 16 & 5.298 & 7.086 \\
\hline 7 & 27 & 28 & & & & & & 299 & 240 & 80.268 & 78.716 & 38 & 15.833 & 17.526 & 23 & 7.692 & 7.268 \\
\hline 8 & 31 & 32 & & & & & & 294 & 212 & 72.109 & 76.734 & 51 & 24.057 & 19.485 & 31 & 10.544 & 8.251 \\
\hline 9 & 35 & 36 & & & & & & 298 & 242 & 81.208 & \begin{tabular}{ll|}
78.076 \\
\end{tabular} & 29 & 11.983 & 17.235 & 26 & 8.725 & 8.393 \\
\hline 10 & 39 & 40 & & & & & & 296 & 214 & $\begin{array}{l}72.297 \\
\end{array}$ & 76.343 & 54 & 25.234 & 19.634 & 17 & 5.743 & 7.598 \\
\hline 11 & 43 & 44 & & & & & & 297 & 233 & 78.451 & 76.975 & 44 & 18.884 & 19.409 & 12 & 4.040 & 6.531 \\
\hline 12 & \begin{tabular}{|l|}
47 \\
\end{tabular} & 48 & & & & & & 300 & 223 & 74.333 & 76.183 & 45 & 20.179 & 19.640 & 28 & 9.333 & 7.372 \\
\hline 13 & 51 & 52 & & & & & & 294 & 226 & 76.871 & \begin{tabular}{ll|}
76.389 \\
\end{tabular} & \begin{tabular}{l|l|}
47 \\
\end{tabular} & 20.796 & 19.987 & 33 & 11.224 & 8.527 \\
\hline 14 & 55 & 56 & & & & & & 290 & 229 & 78.966 & 77.162 & 46 & 20.087 & 20.017 & 18 & 6.207 & 7.831 \\
\hline 15 & 59 & 60 & & & & & & 293 & 217 & 74.061 & 76.232 & 59 & 27.189 & 22.169 & 14 & 4.778 & 6.915 \\
\hline 16 & 63 & 64 & & & & & & 295 & 220 & $\begin{array}{l}74.576 \\
\end{array}$ & 75.735 & 55 & 25.000 & 23.018 & 16 & 5.424 & 6.468 \\
\hline 17 & 67 & 68 & & & & & & 296 & 214 & 72.297 & 74.704 & 64 & 29.907 & 25.085 & 8 & 2.703 & 5.338 \\
\hline 18 & 71 & 72 & & & & & & 310 & 228 & 73.548 & 74.357 & \begin{tabular}{ll|}
68 \\
\end{tabular} & 29.825 & 26.507 & 16 & 5.161 & 5.285 \\
\hline 19 & 75 & 76 & & & & & & 297 & 204 & $\begin{array}{l}68.687 \\
\end{array}$ & 72.656 & 78 & 38.235 & 30.025 & 8 & 2.694 & 4.508 \\
\hline 20 & 79 & 80 & & & & & & 302 & 223 & 73.841 & 73.012 & 60 & 26.906 & 29.089 & 6 & 1.987 & 3.751 \\
\hline 21 & 80 & 81 & & & & & & 299 & 219 & 73.244 & 73.081 & 63 & 28.767 & 28.993 & 9 & 3.010 & 3.529 \\
\hline 22 & 81 & 82 & & ᄃิ & $\underline{U}$ & & & 299 & 213 & $\begin{array}{l}71.237 \\
\end{array}$ & 72.528 & 61 & 28.638 & 28.886 & 4 & 1.338 & 2.872 \\
\hline 23 & 82 & 83 & & $N$ & டे & & & 299 & 209 & 69.900 & 71.740 & 59 & 28.230 & 28.689 & 10 & 3.344 & 3.013 \\
\hline 24 & 83 & 84 & & $n$ & $N$ & & & 297 & 180 & 60.606 & 68.400 & 78 & 43.333 & 33.083 & 6 & 2.020 & 2.716 \\
\hline 25 & 84 & 85 & & $\stackrel{0}{0}$ & $\frac{0}{7}$ & & & 292 & 148 & 50.685 & 63.085 & 86 & 58.108 & 40.590 & 5 & 1.712 & 2.415 \\
\hline 26 & 88 & 89 & & $\div$ & $\vec{n}$ & & & 304 & 175 & 57.566 & \begin{tabular}{l|l}
61.429 \\
\end{tabular} & 78 & 44.571 & 41.785 & 4 & 1.316 & 2.085 \\
\hline 27 & 92 & 93 & & $\approx$ & 0 & & & 298 & 189 & 63.423 & $\begin{array}{l}62.027 \\
\end{array}$ & 71 & 37.566 & 40.519 & 5 & 1.678 & 1.963 \\
\hline 28 & 96 & 97 & 0 & $\stackrel{\Sigma}{\Sigma}$ & $\frac{\pi}{0}$ & & & 300 & 181 & 60.333 & 61.519 & 78 & 43.094 & 41.292 & 3 & 1.000 & 1.674 \\
\hline 29 & 100 & 101 & $\frac{c}{\alpha}$ & $\underset{\pi}{\pi}$ & 츤 & & & 297 & 187 & 62.963 & 61.952 & 75 & 40.107 & 40.936 & 1 & 0.337 & 1.273 \\
\hline 30 & \begin{tabular}{|l|}
104 \\
\end{tabular} & 105 & u & 8 & 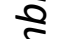 & & & 303 & 204 & 67.327 & 63.565 & 66 & 32.353 & 38.361 & 0 & 0.000 & 0.891 \\
\hline 31 & \begin{tabular}{|l|}
108 \\
\end{tabular} & 109 & 으 & $\approx$ & 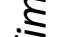 & & & 298 & 211 & 70.805 & $\begin{array}{l}65.737 \\
6\end{array}$ & \begin{tabular}{ll|}
67 \\
\end{tabular} & 31.754 & 36.379 & 1 & 0.336 & 0.724 \\
\hline 32 & \begin{tabular}{|l|}
112 \\
\end{tabular} & \begin{tabular}{|l|}
113 \\
\end{tabular} & 으 & ऽ & 5 & & & 295 & 202 & 68.475 & 66.558 & 66 & 32.673 & 35.267 & 7 & 2.373 & 1.219 \\
\hline 33 & \begin{tabular}{|l|}
116 \\
\end{tabular} & 117 & & & $\stackrel{9}{2}$ & & & 302 & 219 & $\begin{array}{l}72.517 \\
\end{array}$ & 68.346 & 52 & 23.744 & 31.810 & 9 & 2.980 & 1.747 \\
\hline 34 & 120 & \begin{tabular}{|l|}
121 \\
\end{tabular} & & $\stackrel{9}{=}$ & $\bar{\sigma}$ & & & 298 & 199 & 66.779 & \begin{tabular}{c|c|}
67.876 \\
\end{tabular} & 57 & 28.643 & 30.860 & 0 & 0.000 & 1.223 \\
\hline 35 & \begin{tabular}{|l|}
124 \\
\end{tabular} & 125 & & $=$ & 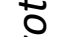 & & & 306 & 186 & 60.784 & 65.748 & 81 & \begin{tabular}{ll|}
43.548 \\
\end{tabular} & 34.667 & 9 & 2.941 & 1.739 \\
\hline 36 & \begin{tabular}{|l|}
128 \\
\end{tabular} & 129 & & \pm & 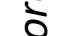 & & & 301 & 206 & 68.439 & 66.555 & 62 & 30.097 & 33.296 & 8 & 2.658 & 2.014 \\
\hline 37 & \begin{tabular}{|l|}
132 \\
\end{tabular} & \begin{tabular}{|l|l|}
133 \\
\end{tabular} & & 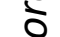 & $=$ & & & 306 & 210 & $\begin{array}{l}68.627 \\
\end{array}$ & 67.177 & 57 & 27.143 & 31.450 & 22 & 7.190 & 3.567 \\
\hline 38 & \begin{tabular}{|l|}
136 \\
\end{tabular} & \begin{tabular}{|l|}
137 \\
\end{tabular} & & 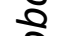 & ? & & & 307 & 216 & 70.358 & 68.131 & 64 & 29.630 & 30.904 & 20 & 6.515 & 4.451 \\
\hline 39 & \begin{tabular}{|l|}
140 \\
\end{tabular} & \begin{tabular}{|l|}
141 \\
\end{tabular} & & 5 & V & & & 300 & 216 & 72.000 & 69.292 & 53 & 24.537 & 28.994 & 26 & 8.667 & 5.716 \\
\hline 40 & \begin{tabular}{|l|}
144 \\
\end{tabular} & 145 & & 0 & & & & 293 & 201 & 68.601 & 69.085 & 56 & 27.861 & 28.654 & 23 & 7.850 & 6.356 \\
\hline 41 & \begin{tabular}{|l|}
148 \\
\end{tabular} & 149 & & & & & & 309 & 192 & 62.136 & 67.000 & 80 & 41.667 & 32.558 & 26 & 8.414 & 6.974 \\
\hline 42 & \begin{tabular}{|l|}
152 \\
\end{tabular} & \begin{tabular}{|l|l|}
153 \\
\end{tabular} & & & & & & 304 & 218 & 71.711 & 68.413 & 57 & 26.147 & 30.634 & 24 & 7.895 & 7.250 \\
\hline 43 & \begin{tabular}{|l|}
156 \\
\end{tabular} & 157 & & & & & & 303 & 208 & 68.647 & 68.483 & 54 & 25.962 & 29.233 & 12 & 3.960 & 6.263 \\
\hline 44 & \begin{tabular}{|l|}
160 \\
\end{tabular} & \begin{tabular}{|l|}
161 \\
\end{tabular} & & & & & & 302 & 226 & 74.834 & 70.389 & 61 & 26.991 & 28.560 & 23 & 7.616 & 6.669 \\
\hline 45 & \begin{tabular}{|l|}
164 \\
\end{tabular} & 165 & & & & & & 298 & 208 & 69.799 & 70.212 & 67 & 32.212 & 29.656 & 29 & 9.732 & 7.588 \\
\hline 46 & \begin{tabular}{|l|}
168 \\
\end{tabular} & 169 & & & & & & 296 & 218 & 73.649 & 71.243 & 54 & 24.771 & 28.190 & 22 & 7.432 & 7.541 \\
\hline 47 & \begin{tabular}{|l|}
172 \\
\end{tabular} & \begin{tabular}{|l|l|}
173 \\
\end{tabular} & & & & & & 300 & 222 & 74.000 & 72.070 & 57 & 25.676 & 27.436 & 18 & 6.000 & 7.079 \\
\hline 48 & \begin{tabular}{|l|}
176 \\
\end{tabular} & \begin{tabular}{|l|}
177 \\
\end{tabular} & & & & & & 301 & 223 & 74.086 & 72.675 & \begin{tabular}{l|l}
43 \\
\end{tabular} & 19.283 & 24.990 & 17 & 5.648 & 6.649 \\
\hline 49 & \begin{tabular}{|l|}
180 \\
\end{tabular} & \begin{tabular}{|l|}
181 \\
\end{tabular} & & & & & & 296 & 211 & 71.284 & 72.258 & 59 & 27.962 & 25.881 & 13 & 4.392 & 5.972 \\
\hline 50 & \begin{tabular}{|l|}
184 \\
\end{tabular} & 185 & & & & & & 299 & 198 & 66.221 & 70.446 & \begin{tabular}{l|l}
63 \\
\end{tabular} & 31.818 & 27.662 & 13 & 4.348 & 5.485 \\
\hline 51 & 188 & 189 & & & & & & 279 & \begin{tabular}{|l|l}
183 \\
\end{tabular} & 65.591 & 68.990 & 59 & 32.240 & 29.036 & 28 & 10.036 & 6.850 \\
\hline 52 & \begin{tabular}{|l|}
192 \\
\end{tabular} & \begin{tabular}{|l|}
193 \\
\end{tabular} & & & & & & 290 & 200 & 68.966 & 68.983 & 56 & 28.000 & 28.725 & 32 & 11.034 & 8.105 \\
\hline 53 & \begin{tabular}{|l|}
196 \\
\end{tabular} & \begin{tabular}{|l|}
197 \\
\end{tabular} & & & & & & 297 & 214 & 72.054 & 69.904 & 55 & 25.701 & 27.818 & 22 & 7.407 & 7.896 \\
\hline 54 & 200 & 201 & & & & & & 297 & 218 & 73.401 & 70.953 & 41 & 18.807 & 25.115 & 33 & 11.111 & 8.861 \\
\hline 55 & \begin{tabular}{|l|}
204 \\
\end{tabular} & 205 & & & & & & 292 & 209 & 71.575 & 71.140 & 50 & 23.923 & 24.757 & 21 & 7.192 & 8.360 \\
\hline 56 & \begin{tabular}{|l|}
208 \\
\end{tabular} & 209 & & & & & & 297 & 201 & 67.677 & 70.101 & 53 & 26.368 & 25.241 & 24 & 8.081 & 8.276 \\
\hline 57 & \begin{tabular}{|l|}
212 \\
\end{tabular} & 213 & & & & & & 293 & 194 & 66.212 & 68.934 & 61 & 31.443 & 27.101 & 24 & 8.191 & 8.251 \\
\hline 58 & \begin{tabular}{|l|}
216 \\
\end{tabular} & 217 & & & & & & 301 & 209 & 69.435 & 69.084 & 68 & 32.536 & 28.732 & 28 & 9.302 & 8.566 \\
\hline 59 & \begin{tabular}{|l|}
220 \\
\end{tabular} & 221 & & & & Globorotalia truncatulinoides, & & 291 & 211 & 72.509 & 70.112 & 56 & 26.540 & 28.074 & 32 & 10.997 & 9.295 \\
\hline 60 & 222 & 223 & & & & Globorotalia fimbriata $\rightarrow$ & & 289 & 199 & 68.858 & & 56 & 28.141 & & 29 & 10.035 & \\
\hline
\end{tabular}




\section{Supplementary Material 3}

\section{ST13 Planktonic Foraminifera Distribution}

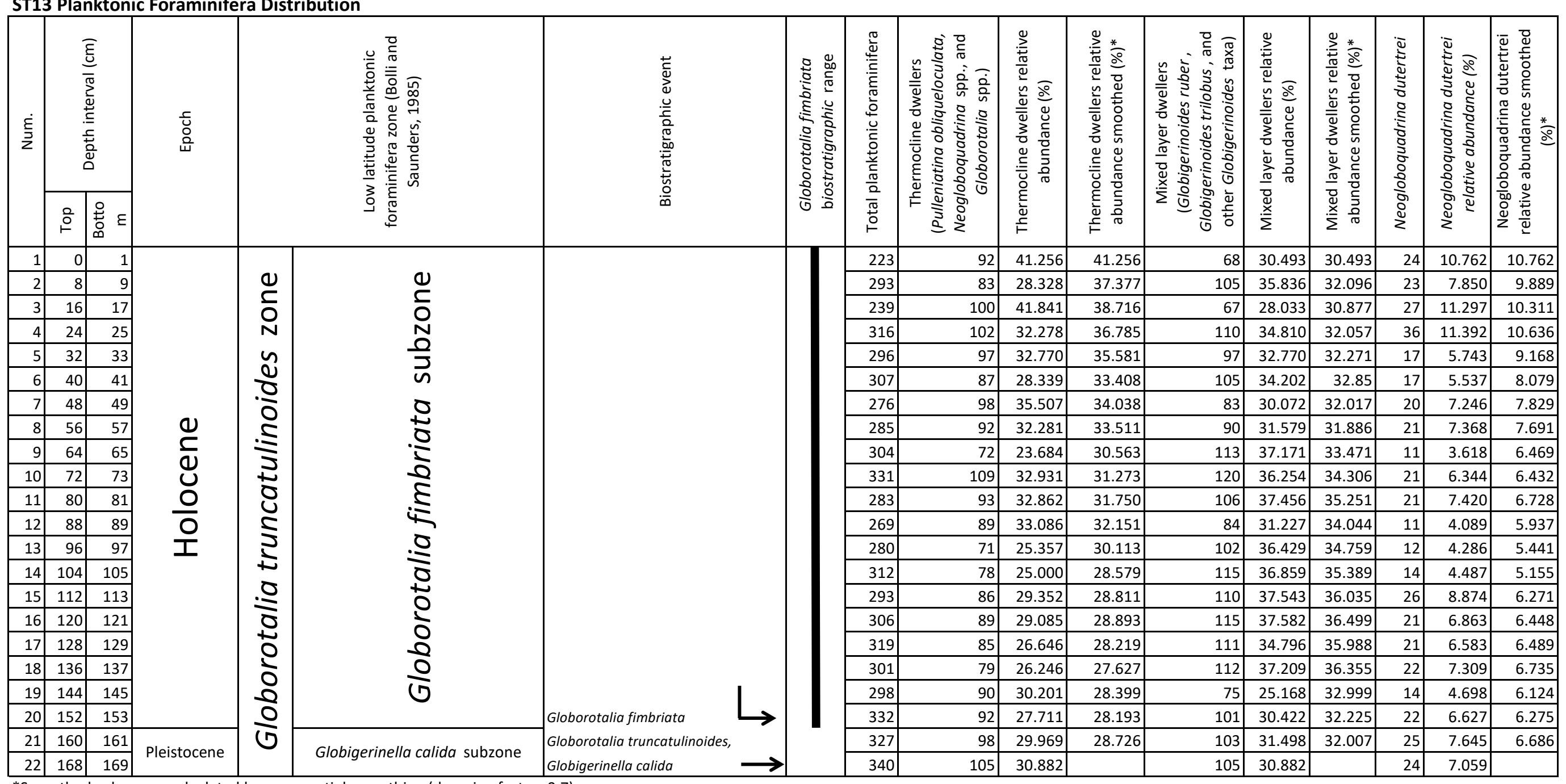

*Smoothed values are calculated by exponential smoothing (damping factor: 0.7 )

L

First Occurrence

Occurrence

Rudarsko-geološko-naftni zbornik i autori (The Mining-Geology-Petroleum Engineering Bulletin and the authors) ( $)$, 2021, 
Supplementary Material 4

ST14 Planktonic Foraminifera Distribution

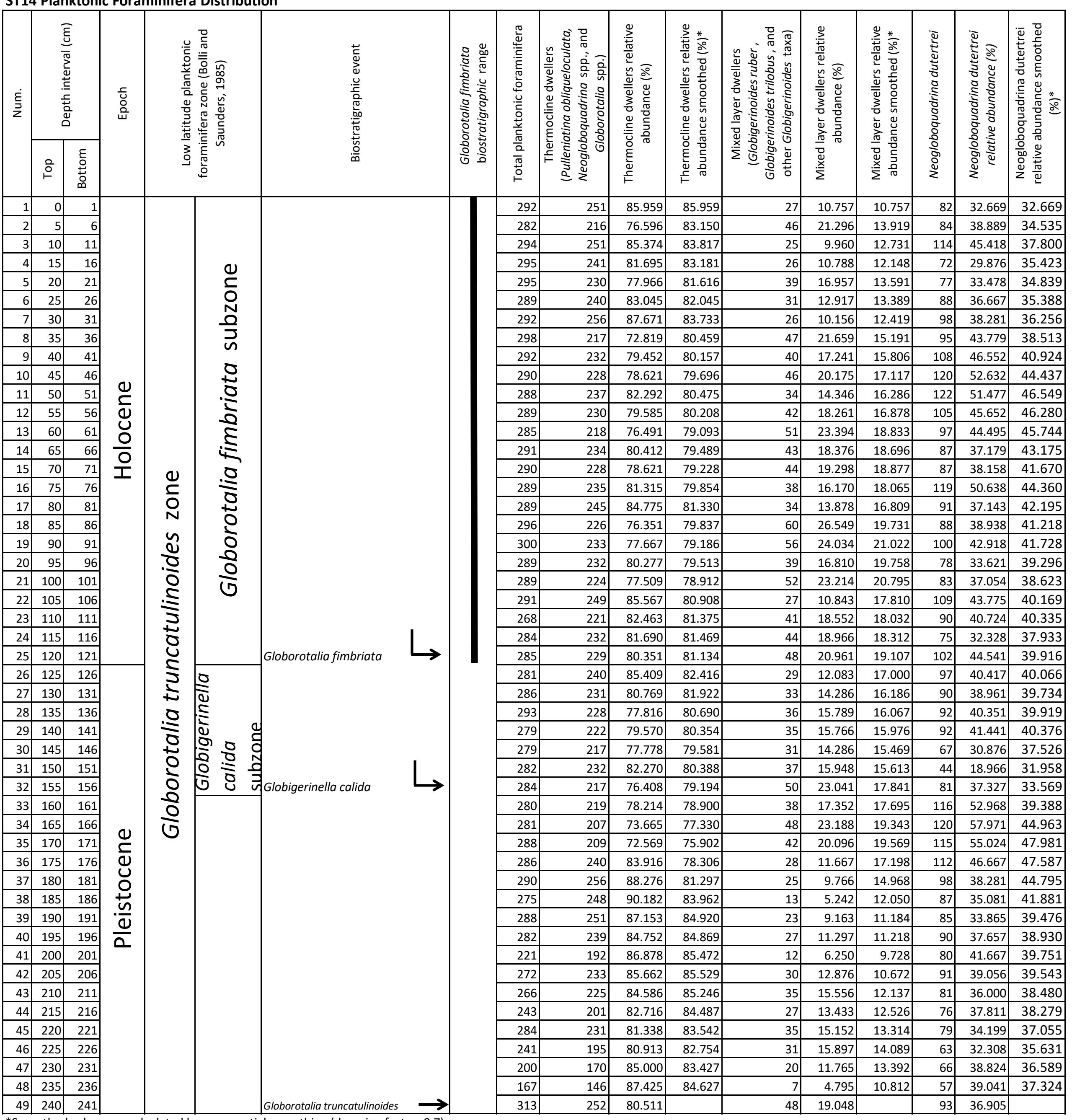

*Smoothed values are calculated by exponential smoothing (damping factor: 0.7 )

First Occurrence

Occurrence 